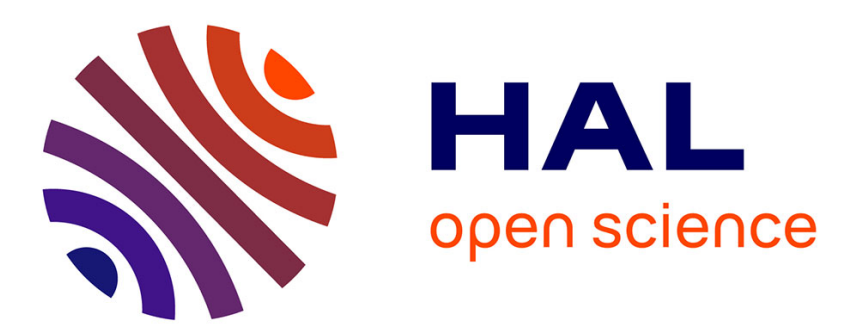

\title{
Assessing biological oxidative damage induced by graphene-based materials: An asset for grouping approaches using the FRAS assay
}

Salma Achawi, Bruno Feneon, Jérémie Pourchez, Valérie Forest

\section{- To cite this version:}

Salma Achawi, Bruno Feneon, Jérémie Pourchez, Valérie Forest. Assessing biological oxidative damage induced by graphene-based materials: An asset for grouping approaches using the FRAS assay. Regulatory Toxicology and Pharmacology, 2021, 127, pp.105067. 10.1016/j.yrtph.2021.105067 . hal03400791

\section{HAL Id: hal-03400791 \\ https://hal.science/hal-03400791}

Submitted on 25 Oct 2021

HAL is a multi-disciplinary open access archive for the deposit and dissemination of scientific research documents, whether they are published or not. The documents may come from teaching and research institutions in France or abroad, or from public or private research centers.
L'archive ouverte pluridisciplinaire HAL, est destinée au dépôt et à la diffusion de documents scientifiques de niveau recherche, publiés ou non, émanant des établissements d'enseignement et de recherche français ou étrangers, des laboratoires publics ou privés. 
Assessing biological oxidative damage induced by graphene-based materials: an asset for grouping approaches using the FRAS assay.

Salma Achawi ${ }^{a, b}$, Bruno Feneon ${ }^{a}$, Jérémie Pourchez ${ }^{b}$, and Valérie Forest ${ }^{b *}$

${ }^{a}$ Manufacture Française des Pneumatiques Michelin, Place des Carmes Déchaux, 63040 ClermontFerrand Cedex 9, France

${ }^{\mathrm{b}}$ Mines Saint-Etienne, Univ Lyon, Univ Jean Monnet, INSERM, U1059 Sainbiose, Centre CIS, F-42023 Saint-Etienne, France.

* Corresponding author: Valérie Forest:

Mines Saint-Etienne, 158 cours Fauriel, CS 62362, 42023 Saint-Etienne Cedex 2. France.

Email:vforest@emse.fr 


\section{Abstract}

Graphene-based materials (GBMs) are extremely promising and their increasing number urges scientists to conduct more and more toxicity studies. However, case-by-case approaches are rarely the best options in the earliest phases of industrial processes. Grouping can show great assets in this context: it is defined as the process of gathering substances into a common group. Oxidative stress being a major mechanism of nanotoxicity, an important grouping criterion is the surface reactivity, for which a relevant assessment is the FRAS (ferric reducing ability of the serum) assay. However, the application of the FRAS to GBMs is questioned due to their hydrophobicity. In this study, we explored the relevance and feasibility of the FRAS for grouping, working on 22 GBMs and 2 carbon blacks. We concluded that with few adjustments, the FRAS method appeared perfectly adapted to these materials and allowed a classification as "reactive" or "non-reactive" in agreement with results of ROS production for $84 \%$ of our GBMs. While not self-sufficient for toxicity assessment, the FRAS presents interesting qualities: it is fast, cheap, and simple. Therefore, we recommend studying GBMs using the FRAS as a step of a grouping process, a complement to other assays or as an early screening tool.

Keywords: Graphene-based materials, Screening, Grouping, FRAS, Oxidative stress, Biological oxidative Damage, Surface reactivity. 


\section{Introduction}

Graphene, a $\mathrm{sp}^{2}$ hybridized carbon nanomaterial of one atom thickness, is considered as one of the strongest materials tested (Lee et al., 2008) and has numerous other physical properties that make it among the most promising materials of this decade (Novoselov et al., 2012). Its applicability is extremely wide, and its market share is planned to increase exponentially (Reiss et al., 2019) positioning it as an inescapable nanomaterial for the following years. The Graphene based materials (GBMs) family is large and includes different kinds of materials such as graphene oxide (GOs), graphene nanoplatelets (GNPs) or reduced graphene oxides (rGOs) which all derived from graphite.

To ensure the integration of not only performant but also safe GBMs in the market, their toxicity needs to be thoroughly assessed. Moreover, it is now well-known that GBMs' toxicity varies depending on their physicochemical characteristics (Achawi et al., 2021), which confirms the need to test each nanoform within the same family. Nanotoxicity is a challenging field: to optimize the toxicity assessment of nanomaterials and their risk management, few methods can be proposed, including grouping. Grouping is defined as the process of uniting substances into a common group if they are structurally similar with physicochemical, (eco)toxicological, and/or environmental interaction properties that are likely to be similar or to follow a regular pattern (Giusti et al., 2019). This promising method could avoid laborious case-by-case approaches, but still needs more data to be completely functional (Dekkers et al., 2016).

For a grouping approach, one must decide which toxicity endpoints will be considered for classification purposes. The European Centre for Ecotoxicology and Toxicology of Chemicals (ECETOC) 'Nano Task Force' proposed a decision-making framework for the grouping and testing of nanomaterials (DF4nanoGrouping) (Arts et al., 2015). Its main goal is to assign nanomaterials in one of the 4 following groups depending on their expected mode of action: (1) soluble nanomaterials, (2) bio persistent high aspect ratio nanomaterials, (3) passive nanomaterials, and (4) active nanomaterials. Nanomaterials' expected mode of action is strongly dependent of their properties. Therefore, properties such as dissolution rate or in vitro effects can help classifying materials among the 4 classes. The classification 
process also integrates bio-physical interactions such as surface reactivity. In other ECETOC approaches such as NanoApp (Janer et al., 2021) which aims to create sets of similar nanoforms, surface reactivity (which can be measured with FRAS, EPR or DCF assay) is also one of the criteria that can be used to classify nanoforms as similar.

Returning to the GBMs, the grouping method could be a great asset as it would represent an early toxicity assessment, allowing industries and scientists to focus on materials that appear to show a minor toxicity impact. GBMs' most well-known mode of action is oxidative stress (Mittal et al., 2016) (Pelin et al., 2018) (Ou et al., 2016) which can be measured by various analytical methods: in vitro cellular testing can for example measure the production of reactive oxygen species or the depletion of antioxidants induced by the nanomaterial while cell free assays can be useful for measuring nanomaterial's intrinsic reactive potential or the biological oxidative damage produced on human matrix. Among these methods, the FRAS (Ferric reducing ability of the serum) assay was pointed as particularly interesting in view of its sensitivity (Hellack et al., 2017).

The FRAS assay measures biological oxidative damage produced on a human matrix through the measurement of the surface reactivity of a nanomaterial in cell free conditions. Available surface of nanomaterials being one of their most important aspect impacting toxicity (Karakoti et al., 2006), surface reactivity has a major role in all types of interaction with the environment, strongly driving health hazard (Magro et al., 2018) (Warheit, Reed and Sayes, 2009). A method published in 1996 described the ferric reducing ability of plasma (FRAP) (Benzie and Strain, 1996) and aimed to measure the antioxidant power of a chosen biological matrix: plasma. Serum was then presented as an interesting alternative to plasma as it does not include coagulation factors which can cause interferences with the assay (Rogers et al., 2008). The FRAP assay finally became the FRAS assay. Other approaches exist, such as the FRAN (ferric reducing ability of nanoparticles) where redox reactions are observed directly on nanoparticles' surface (Bi and Westerhoff, 2019).

FRAS protocol shows interesting assets as it is simple, reproducible and already widely used to measure the antioxidant capacity of a biological matrix in the framework of clinical studies (Gawron-Skarbek et 
al., 2019) or in vivo measurements (Cecchini and Fazio, 2020). However, in the framework of DF4 nanogrouping, surface reactivity of GBMs could not be assessed using FRAS, which was considered unsuitable for such insoluble materials (Arts et al., 2016). GBMs were indeed not expected to disperse properly enough to be able to observe any change in the exposed serum properties.

Gandon et al. recently published a protocol of the FRAS measurement, adapted for grouping or read across methods, and optimized for nanomaterials (Gandon et al., 2017). We worked on this protocol, and slightly modified it. Using a wide range of GBMs, we demonstrated the feasibility of FRAS assay for GBMs Moreover, we aimed to make this protocol even easier to work with by thoroughly describing the protocol step by step. Lastly, we intended to propose a quicker version of this protocol, enabling us to work on 3 nanomaterials a day.

In this paper, we demonstrate that an adapted FRAS protocol can be a fast, straightforward, and efficient way to measure GBMs' surface reactivity. We also discuss the relevance of FRAS assay as a grouping endpoint by comparing its results to the ROS production measured in a macrophage cell line through the DCF-DA assay.

\section{Material and Methods}

\subsection{Nanomaterials}

To evaluate the feasibility of FRAS assay on GBMs we used a wide range of GBMs, espcially graphene nanoplatelets (GNPs) and reduced graphene oxide ( $\mathrm{rGO}$ ). Their specific surface area (SSA) was determined with BET technique (adsorption of nitrogen, with degassing system Micromeritics). Their surface oxidation was determined with XPS (X-ray Photo spectroscopy, Quantera Scanning XPS microprobe, Physical Electronics). Lateral size was determined with electronic microscopy (Field Emission Scanning Electron Microscope, from JEOL). ID/IG ratio was calculated with RAMAN spectroscopy (XploRA, Horiba Scientific). For comparison, we also tested two samples of carbon black (CB) and one sample of amorphous silica and $\mathrm{Mn}_{2} \mathrm{O}_{3}$ as positive control. All these samples are listed in Table 1. In supplementary data 1, ICP and XPS analyses and the RAMAN spectra are reported. 
Table 1 - Samples tested in our study and their physicochemical characterization.

\begin{tabular}{|c|c|c|c|c|}
\hline & $\begin{array}{l}\text { Surface Oxidation } \\
\qquad(\% \mathrm{O})\end{array}$ & $\begin{array}{c}\text { Mean Lateral Size } \\
\qquad(\mu \mathrm{m})\end{array}$ & $\begin{array}{l}\text { Surface defects } \\
\text { (ID/IG) }\end{array}$ & $\begin{array}{c}\text { Specific Surface } \\
\text { Area }\left(\mathrm{m}^{2} / \mathrm{g}\right)\end{array}$ \\
\hline GNP1 & 3.2 & 1.25 & 0.369 & 283 \\
\hline GNP2 & 6.3 & 0.66 & 0.470 & 439 \\
\hline GNP3 & 7.6 & 0.53 & 0.724 & 692 \\
\hline GNP4 & 4.3 & 3.56 & 0.340 & 38 \\
\hline GNP5 & 3.3 & 5.58 & 0.062 & 41 \\
\hline GNP6 & 2.6 & 7.91 & 0.146 & 48 \\
\hline GNP7 & 4.2 & 10.86 & 0.101 & 89 \\
\hline GNP8 & 5.9 & 17.34 & 0.634 & 168 \\
\hline GNP9 & 5.7 & 38.57 & 0.068 & 119 \\
\hline GNP10 & 2.1 & 33.54 & 0.132 & 34 \\
\hline GNP11 & 2.5 & 30.70 & 0.225 & 31 \\
\hline GNP12 & 6.1 & 1.63 & 0.348 & 396 \\
\hline GNP13 & 4.4 & 3.16 & 0.645 & 125 \\
\hline GNP14 & 4.5 & 1.51 & 0.346 & 335 \\
\hline GNP15 & 3.5 & 2.02 & 0.321 & 255 \\
\hline rGO3 & 11.9 & 8.26 & 1.038 & 545 \\
\hline rGO4 & 7.2 & 31.56 & 0.937 & 880 \\
\hline rGO5 & 2.7 & 6.99 & 1.066 & 830 \\
\hline rGO6 & 15.9 & 32.01 & 0.905 & 270 \\
\hline rGO7 & 6.7 & 15.1 & 0.957 & 810 \\
\hline rGO8 & 17.2 & 1.04 & 0.908 & 440 \\
\hline rGO9 & 2.6 & 1.11 & 1.066 & 870 \\
\hline CB1 & 2.6 & 0.36 & NA & 112 \\
\hline CB2 & 2.3 & 0.9 & NA & 85 \\
\hline Amorphous Silica & 70.0 & 0.09 & NA & 160 \\
\hline $\mathrm{Mn}_{2} \mathrm{O}_{3}$ (grade 1) & NA & NA & NA & 1.7 \\
\hline $\mathrm{Mn}_{2} \mathrm{O}_{3}$ (grade 2) & NA & NA & NA & 18.7 \\
\hline
\end{tabular}

\subsection{Development of a FRAS assay protocol adapted to GBMs}

The principle of this method is to measure the antioxidant ability of a matrix exposed to a chemical through the observation of its ferric reducing capacity. The ferric reducing capacity can be considered as an analog of the antioxidant power (Hsieh et al., 2013) (Piątek-Guziewicz et al., 2017). Indeed, the chemical reaction of taking an electron from an atom is oxidation, whereas the opposite chemical reaction of giving an electron to an atom is the reduction. Hence, the FRAS assay principle is to measure 
the capacity of a serum sample which has been exposed to nanomaterials (or any other chemicals) to reduce ferric ions to ferrous ions. Figure 1 briefly presents the concept of the FRAS assay.

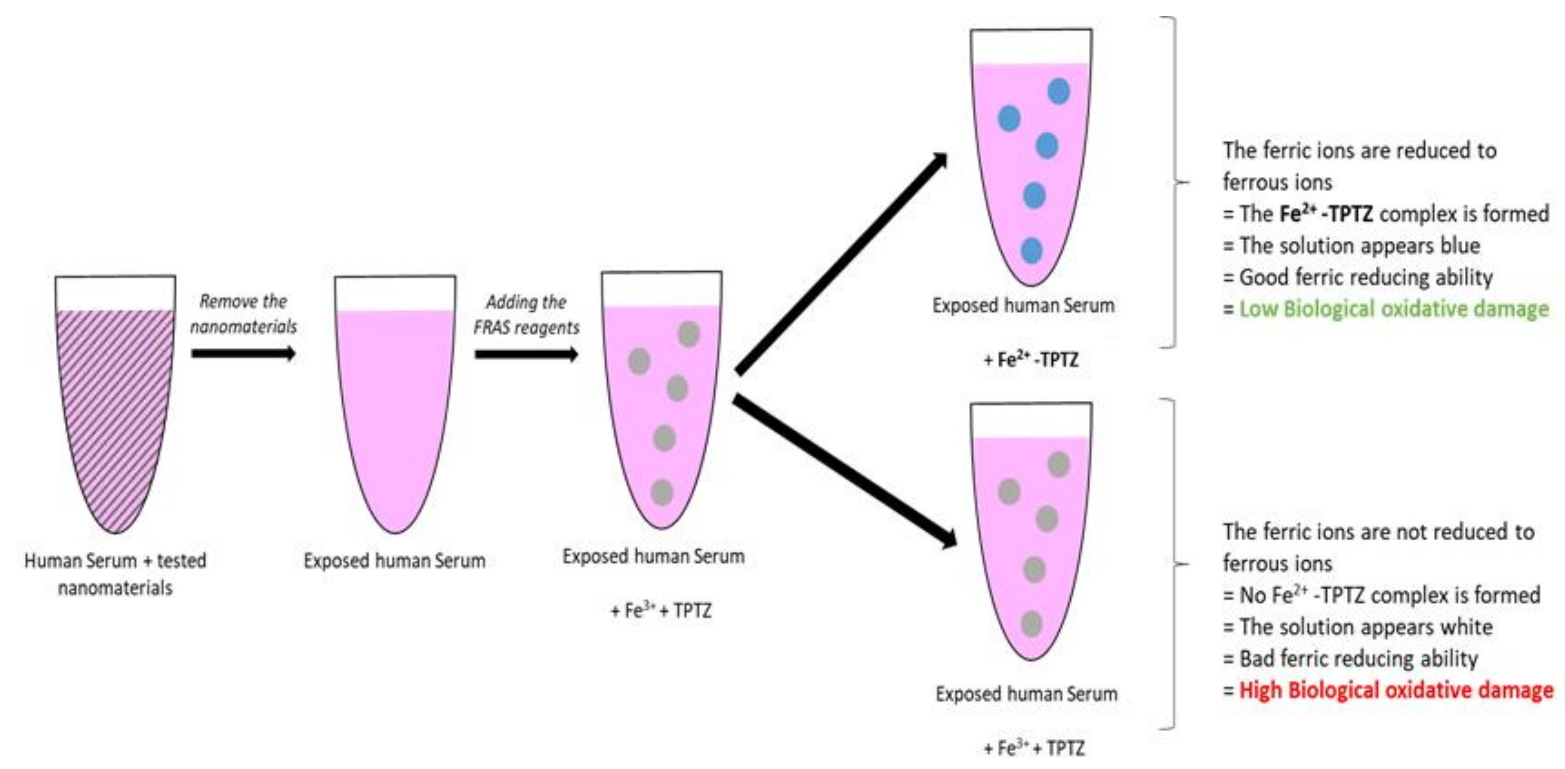

Figure 1: Presentation of the FRAS assay.

Our protocol is driven by the work of Gandon et al. published in 2017. We present the full protocol in supplementary data 2 and list necessary equipment and chemicals in supplementary data 3. Briefly, we prepared solutions of human blood serum and nanomaterials at concentration of 5, 10 and $20 \mathrm{~g} / \mathrm{L}$. We incubated the HBS-NM solutions during 3 hours at $37^{\circ} \mathrm{C}$ (ThermoMixer, Fisher). We then separated the NM from the exposed human blood serum though a centrifugation (Heraeus Megafuge Centrifuge, Thermo). Lastly, we collected the HBS supernatant and added it to FRAS reagent, allowing FRAS reaction. After a 60-minute reaction time, we measured the absorbance (Spectrophotometer MULTISKAN, Thermo) of each sample (see supplementary data 4 for labelling the vials for this assay). We modified few steps from the protocol from Gandon et al. to optimize this assay to our needs and the use on GBMs. These modifications are described in supplementary data 2.

To analyze the data, a calibration curve was established using Trolox, an equivalent of vitamin E (see calibration step in supplementary data 2, and analysis section 2.4.1). 


\subsection{Specificities of low density GBMs}

We worked on a wide range of GBMs to make sure that this method was feasible for all of them. We encountered some difficulties with very low density GBMs. Some rGOs have a very low density and preparing a high concentration with these nanomaterials can be challenging especially when the powders occupied a larger volume than the HBS. In these conditions, we did not prepare $20 \mathrm{~g} / \mathrm{L}$ concentrations for $\mathrm{rGO} 4, \mathrm{rGO}$, rGO6, rGO7, rGO8 and rG09. The sonication, incubation and centrifugation were strictly the same as for the other tested items. Separating the HBS from the nanomaterials was the most challenging part: our centrifuge could not reach the $11,900 \mathrm{rpm}$ initially required by the protocol written by Gandon et al., and the low density prevented us from removing the nanomaterials before addition of the FRAS reagent. We then chose to separate these particular GBMs with an additional step: after the centrifugation, we collected the supernatant and then filtered it with a syringe filter of $0.2 \mu \mathrm{m}$ to eliminate the remaining nanomaterials (see supplementary data 5).

\subsection{Analysis}

\subsubsection{TROLOX calibration}

This step is essential to convert our results into Trolox equivalent unit (TEU). Trolox $\left(\mathrm{C}_{14} \mathrm{H}_{18} \mathrm{O}_{4}\right)$ is a water-soluble analog of vitamin E and a well-known antioxidant(Arts et al., 2004). To test the ferric reducing ability of our serum exposed to this antioxidant, we replaced the HBS previously exposed to nanomaterials by a series of concentrations of Trolox in water of $0.1,0.05,0.01,0.005$ and $0.001 \mathrm{~g} / \mathrm{L}$. We obtained a FRAS absorption signal that can be linearly fitted with the equation:

$$
A b S_{\text {Trolox }}=k \varepsilon * I * d * C_{\text {Trolox }}+b\left(R^{2}=0.9998\right) \text {. }
$$

Where:

- $\quad$ Abs $=$ Absorption [Arbitrary units]

- I = light path of cuvette [cm]: $0.3 \mathrm{~cm}$ in our case.

- $\mathrm{k} \varepsilon=$ extinction coefficient of the complex $\mathrm{Fe}^{2+} / \mathrm{TPTZ}$ induced by $1 \mathrm{Mol}$ antioxidant [Trolox equivalent unit, TEU] 
- $\mathrm{d}=$ dilution factor 0.048 (0.1 $\mathrm{ml} \mathrm{HBS}$ in $2 \mathrm{ml}$ FRAS reagent)

- $\quad \mathrm{C}_{\text {Trolox }}=$ concentration $[\mathrm{mM}]$

In our case, $\mathrm{kE}^{*} \mathrm{I}^{*} \mathrm{~d}$ was $\mathbf{1 . 9 6 2 5}$ and b, our offset, was $\mathbf{0 . 0 4 8 8}$. In comparison, Gandon et al. obtained $k E^{*} I^{*} d=\mathbf{2 . 6 5 4}$ and an offset of $\mathbf{0 . 0 7 5}$. Please note that the light path of their cuvette was $10 \mathrm{~mm}$ whereas our cuvette measured $3 \mathrm{~mm}$. These data are consistent with our values.

Concretely, we will use these data to convert absorbance units to Trolox equivalent units, enabling us to compare the results between each study. It also enables us to calibrate our test according to the HBS used and the different batches provided. Therefore, if you are using more than one bottle of HBS, consider performing this calibration step for each bottle.

\subsubsection{Conversion in Biological oxidative damage (BOD) surface-based BOD and mass-based} BOD

The main results that we can obtain from the FRAS assay are:

- Biological oxidative damage (BOD) [in mM TEU]: obtained directly with the absorbance and converted in TEU as shown in part 2.4.1.

- Mass-based biological oxidative damage (m-BOD) [in nMTEU /mg]: obtained by dividing BOD by its concentration [in $\mathrm{g} / \mathrm{L}]$.

- Surface-based biological oxidative damage (s-BOD) [in $\mathrm{nMTEU} / \mathrm{m}^{2}$ ]: obtained by dividing the BOD by the dose of nanomaterial (a combination of its concentration [in $\mathrm{g} / \mathrm{L}$ ] and specific surface area $\left[\right.$ in $\left.\left.\mathrm{m}^{2} / \mathrm{g}\right]\right)$.

The equations and explanations for obtaining these values are described in Gandon et al. Moreover, we present a step-by-step analysis of an example in supplementary data 6.

\subsubsection{Positive control}

In the frame of the DF4 nano grouping, nanomaterials are classified depending on $\mathrm{Mn}_{2} \mathrm{O}_{3}$ surface reactivity: this material is indeed the preferred positive control as it is reactive for FRAS assay, band 
gap analysis (Zhang et al., 2012) and cytochrome c assay (Delaval et al., 2016). For the grouping method published by Arts et al., as well as the work of Gandon et al., a specific grade of $\mathrm{Mn}_{2} \mathrm{O}_{3}$ (with a specific surface area of $19.9 \mathrm{~m}^{2} / \mathrm{g}$ ) was used. Unfortunately, this reference is not available anymore. For the sake of a good standardization, we aimed to test the BOD caused by $\mathrm{Mn}_{2} \mathrm{O}_{3}$ within our own experiments. We ordered two different grades of $\mathrm{Mn}_{2} \mathrm{O}_{3}$, differing by their dimension and specific surface area:

- $\mathrm{Mn}_{2} \mathrm{O}_{3}$ Grade $1: \mathrm{SSA}=1.7 \mathrm{~m}^{2} / \mathrm{g}$, particle size 325 mesh (equals to approximately $44 \mu \mathrm{m}$ ).

- $\mathrm{Mn}_{2} \mathrm{O}_{3}$ Grade 2: SSA $=18.7 \mathrm{~m}^{2} / \mathrm{g}$, particle size $60 \mathrm{~nm}$.

With these two samples, we aimed to show how using various grades of the same chemical could impact the results and to test a grade of $\mathrm{Mn}_{2} \mathrm{O}_{3}$ that showed close SSA to the one used in the existing literature.

\subsection{DCFDA Assay}

We wanted to study the potential correlation between the biological oxidative damage induced by NM and their ROS cellular production. To this end, we performed a DCFDA assay to measure the ROS production caused by the exposure of cells to the same GBMs.

RAW 264.7 murine macrophage cell line was provided by ATCC Cell Biology Collection (Promochem LGC). It derived from mice peritoneal macrophages transformed by the Albeson Murine Leukemia Virus. Cells were grown in 10\% fetal calf serum Dulbecco's Modified Eagle Medium (DMEM, Invitrogen) supplemented with $1 \%$ penicillin-streptomycin (Sigma-Aldrich) and maintained at $37^{\circ} \mathrm{C}$ under a $5 \%$ carbon dioxide humidified atmosphere. Cells were exposed to increasing concentrations of GBMs (from 15 to $120 \mu \mathrm{g} / \mathrm{mL}$ ) for 90 minutes. We then measured the ROS production through the OxiSelect ${ }^{\mathrm{TM}}$ Intracellular ROS Assay Kit (STA-342).

\section{Results}

\subsection{Biological oxidative damage induced by GBMs}


Gandon et al. recommends plotting each series of replicates for each nanomaterial with log (Dose) on $x$-axis and $\log (B O D)$ on $y$-axis and to fit with a linear regression curve. However, for reactive materials, a linear curve might not be appropriated and could be replaced with a sigmoid. Indeed, we did not have very good fits for reactive GBMs. We hence decided to calculate a mean BOD (Figure 2A), and SBOD (Figure 2B). Note that for low-density GBMs, we could not prepare a $20 \mathrm{~g} / \mathrm{L}$ solution (see section 2.3).

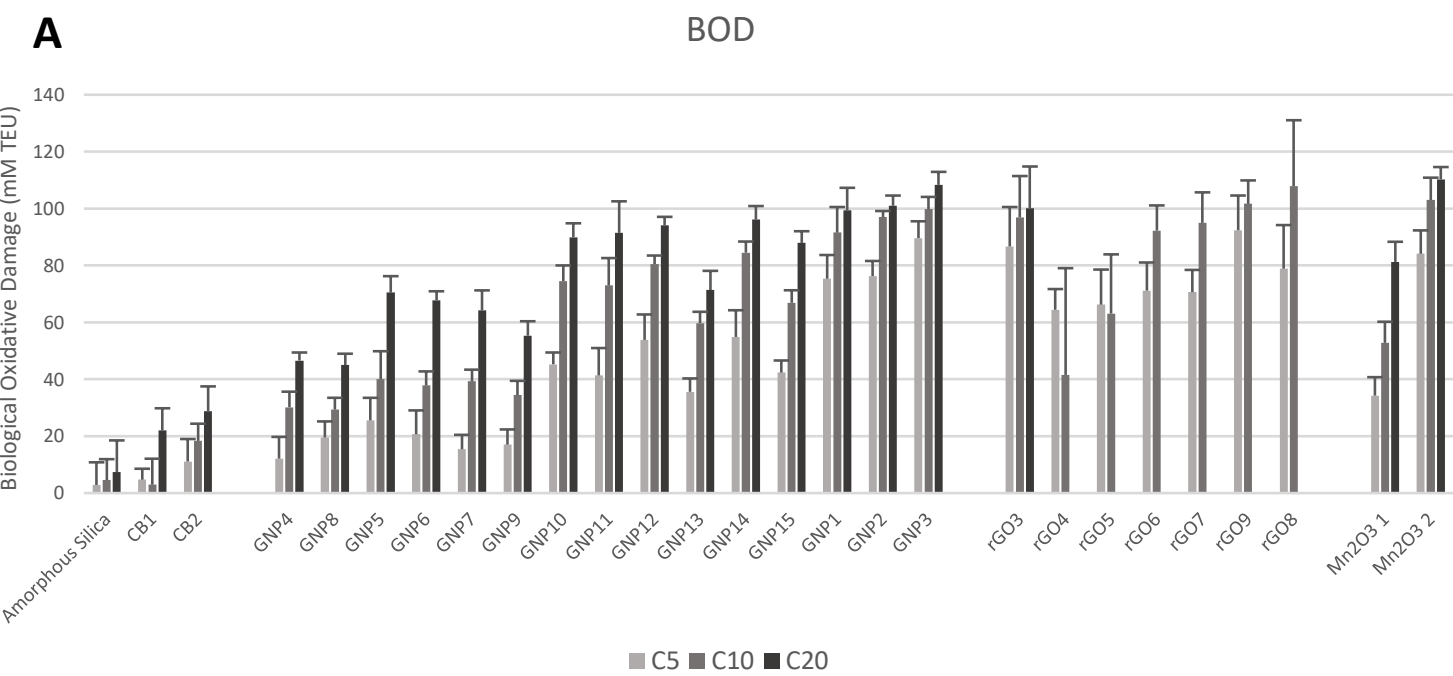

B

sBOD

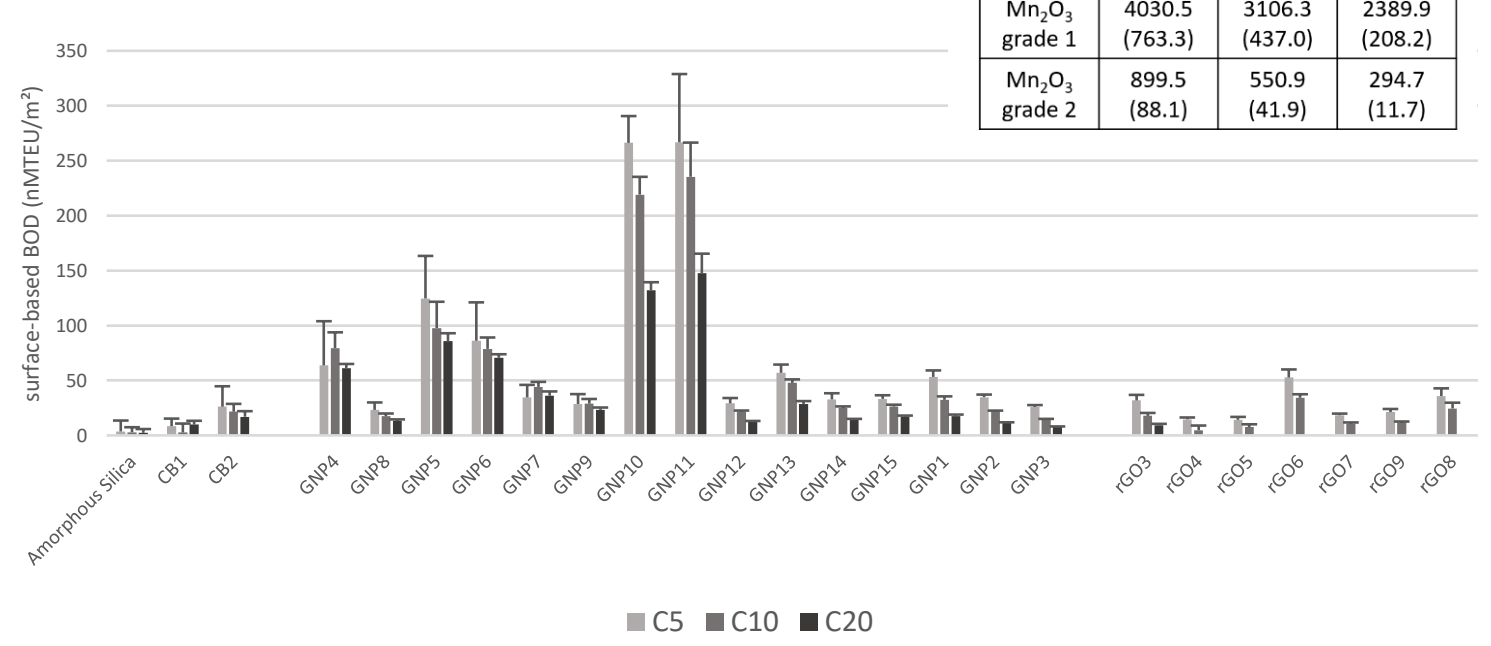

Figure 2: A) Biological oxidative damage (BOD) and B) Surface-based Biological Oxidative Damage (sBOD) (note that the results of $\mathrm{Mn}_{2} \mathrm{O}_{3}$ are presented in a table since the scale was extremely different). 
The biological oxidative damage values induced by GBMs, CB and the amorphous silica are variable and dose dependent. Overall, we can conclude that FRAS assay efficiently measures the BOD induced by various types of GBMs and allows a certain classification of GBMs between each other. However, for some samples (GNP3, $\mathrm{rGO} 3$ or $\mathrm{Mn}_{2} \mathrm{O}_{3}$ grade 2 ), a maximum BOD of approximately 100 mMTEU is reached from the lowest dose $(5 \mathrm{~g} / \mathrm{L})$. As the dose increases, no dose response appears which indicates a probable saturation effect around 100 mMTEU.

Concerning $\mathrm{mBOD}$, as almost every nanomaterial shows a dose dependent $\mathrm{BOD}$, the highest $\mathrm{mBOD}$ can often be measured at $5 \mathrm{~g} / \mathrm{L}$ and can reach $18.5 \mathrm{nMTEU} / \mathrm{mg}$. The values are in the same range than the one previously published (see section 4.1 of discussion).

The SBOD allows considering the surface reactivity for each square meter of material. As shown in section 2.4.2 of Material and methods, it includes the specific surface area and the concentration of the GBMs. We mostly obtain a maximum sBOD at the dose of $5 \mathrm{~g} / \mathrm{L}$. The sBOD are extremely variable, between 0 and $350 \mathrm{nMTEU} / \mathrm{m}^{2}$. Grades 1 and 2 of $\mathrm{Mn}_{2} \mathrm{O}_{3}$, have low SSAs $\left(1.7 \mathrm{~m}^{2} / \mathrm{g}\right.$ and $\left.20 \mathrm{~m}^{2} / \mathrm{g}\right)$ while having strong BODs (up to 81 and 110 mTEU respectively), which automatically leads to an extremely high sBOD (from 2090 to $4010 \mathrm{nMTEU} / \mathrm{m}^{2}$ ). Hence, the two chosen grades of $\mathrm{Mn}_{2} \mathrm{O}_{3}$ show an extremely high sBOD compared to GBMs, CBs and the amorphous silica.

Overall, even with reactive materials such as GBMs, this assay appears to successfully classify GBMs as reactive or not concerning biological oxidative damage.

\subsection{Biological oxidative damage and ROS production induced by GBMs}

For a simple presentation of the results, we chose to present only one exposure concentration for each assay: $5 \mathrm{~g} / \mathrm{L}$ for FRAS assay and $120 \mu \mathrm{g} / \mathrm{mL}$ for DCFDA assay. Also, the FRAS results are indicated in BOD whereas the DCFDA are presented in fold to negative control. The results are presented in Figure 3. 


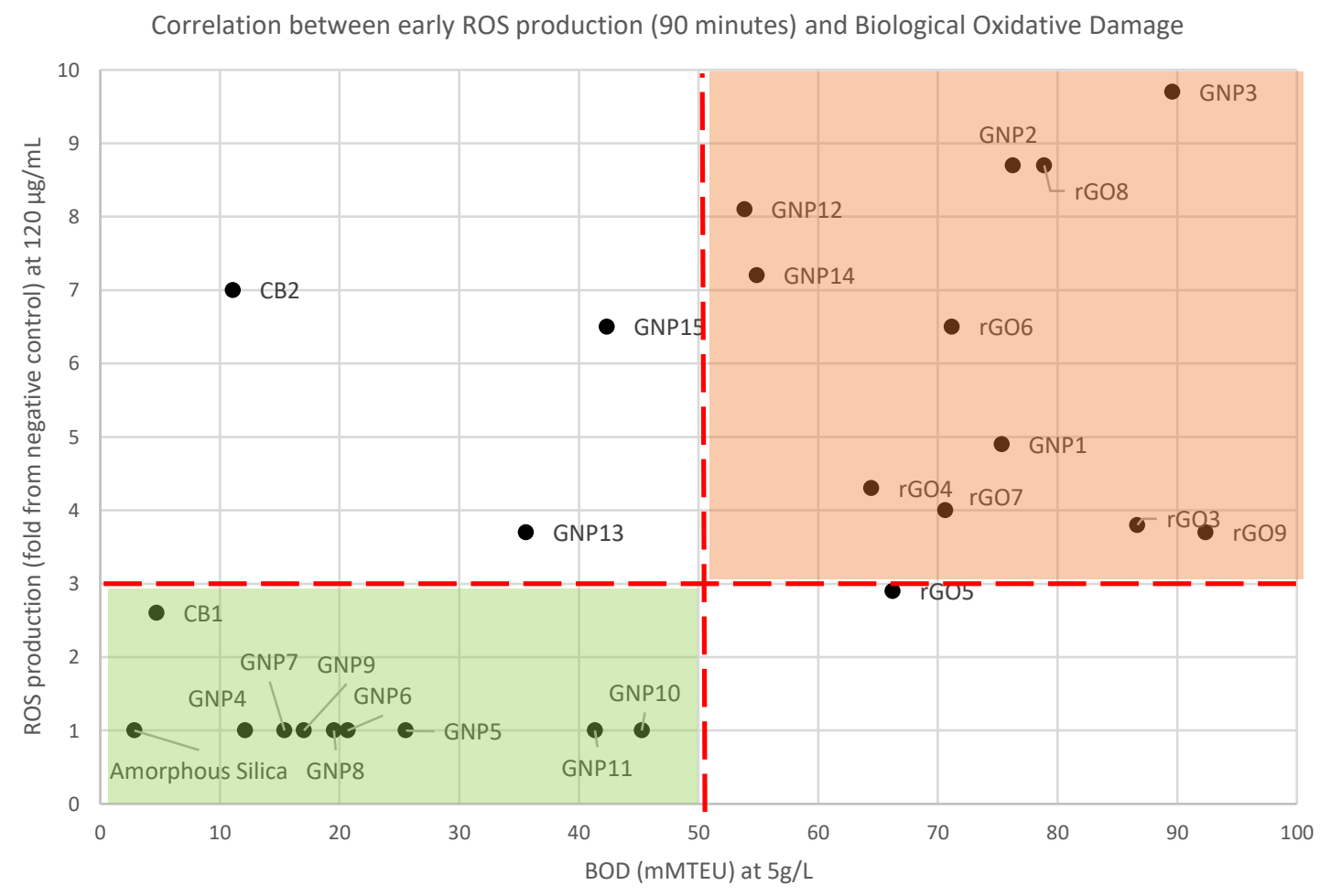

Figure 3: Correlation between early reactive oxygen species (ROS) cellular production and biological oxidative damage (BOD). Early ROS cellular production is considered as high when it hits 3 times the negative control and BOD is considered high when it hits 50 mMTEU. Nanomaterials that have a high ROS production and a high BOD are considered reactive, whereas the ones with low to moderate ROS and BOD are considered non-reactive.

Firstly, we can note a link between the ROS production and the BOD caused by the GBMs. Two main groups of GBMs can also be described. The first one, in green, gathers 10materials exhibiting a low ROS production at high concentration (90 minutes of exposure to $120 \mu \mathrm{g} / \mathrm{mL}$ ) and a low to moderate BOD. The second group, in orange, gathers 11 nanomaterials that show a high BOD combined with an increased ROS production. For information, the tendency is the same for a ROS production measured after a 24-hour exposure time. 4 materials cannot be classified in one of these groups, one of them being a carbon black. 
In conclusion, we can consider that the combination of DCFDA and FRAS appears as an interesting methodology for classifying materials as "reactive" or "non-reactive" for a grouping approach.

\section{Discussion}

\subsection{Values in the literature for FRAS assays}

In the literature, there are only few studies of the FRAS assessment for GBMs or CBs. The papers presenting such results to our knowledge are presented in supplementary data 7. Please note that for an easier reading, all results were converted in the same unit: nM TEU.

Some CBs had their BOD, sBOD and mBOD measured. In our tested samples, the two tested CBs have approximately the same SSA than CB N110. Both our CBs showed a very moderate FRAS effect. We found that for $\mathrm{CB} 1, \mathrm{BOD}$ equals $2.99 \mathrm{mMTEU}$, $\mathrm{SBOD}$ equals $2.7 \mathrm{nMTEU} / \mathrm{m}^{2}$ and $\mathrm{mBOD}$ equals 1.11 nMTEU/mg. In the work published by Hsieh et al (2012), the CB N110 had a mean BOD of 0.937 $\mathrm{mMTEU}$, a sBOD of $80 \mathrm{nMTEU} / \mathrm{m}^{2}$ and $\mathrm{mBOD}$ of $9 \mathrm{nMTEU} / \mathrm{mg}$. These results differ but remain in the same range for BOD.

Concerning GBMs, only Hsieh et al (2013) investigated these materials. A GBM with a SSA around 100 $\mathrm{m}^{2} / \mathrm{g}$ was tested, which could be transposed to GNP9 or GNP15. We do not have a lot of information on the result of physicochemical characterization, so we are relying our comparison on SSA. We found that GNP15 has a sBOD of $48.2 \mathrm{nMTEU} / \mathrm{m}^{2}$ and a $\mathrm{mBOD}$ of $6 \mathrm{nMTEU} / \mathrm{mg}$ and GNP9 has a sBOD of 29.2 $\mathrm{nMTEU} / \mathrm{m}^{2}$ and a mBOD of $3.5 \mathrm{nMTEU} / \mathrm{mg}$. In the work of Hsieh et al (2012), their $2 \mathrm{GBMs}$ had a sBOD of 92 and $103 \mathrm{nMTEU} / \mathrm{m}^{2}$ and a $\mathrm{mBOD}$ of 9 and $10 \mathrm{nMTEU} / \mathrm{mg}$. These results are quite consistent, GNP15 showing closer results with the two tested GBMs in Hsieh et al (2012).

Overall, comparable nanomaterials present the same range of results. The variations can be due to multiple factors: the protocol used that differed, the grade of chemicals used and the grade and source of human blood serum (see supplementary data 8 for blank antioxidant capacity of the serum measurement). 


\subsection{Correlation between biological oxidative damage and ROS production}

FRAS and DCF-DA assay measure different biological endpoints. FRAS acellular assay measures the reducing activity of a serum previously exposed to chemicals which is a proxy of its antioxidant capacity or the biological oxidative damage (BOD) induced by a chemical. DCF-DA is a cellular assay which measures the ROS production of cells previously exposed to chemicals. We performed this assay on murine macrophages (RAW264.7) since these cells are ubiquitous and specialized in foreign substances' elimination.

We observed a potential correlation of the results of these two assays. Two major groups can be distinguished: a group that shows a low pro-oxidant capacity and moderate BOD and a group that shows a high pro-oxidant capacity and high BOD. A vast majority of our samples can be classified in one of these groups. Even if these two assays do not measure the same biological endpoint, it seems that the results of DCF-DA and FRAS assay are quite well-correlated.

Our results are in agreement with a study (Pal et al., 2014) where a correlation was found between an acellular DCF-DA results and a FRAS assay for diverse nanomaterials. This tendency was strengthened with the cellular oxidative stress measurement performed on seven NMs (GSH: GSSG assay performed on THP-1) which appeared to be correlated to the FRAS results.

Recently, different methods for assessment of surface reactivity were tested on a total of 35 nanomaterials (Bahl et al., 2020). A combination of an acellular assay such as FRAS and a cellular assay such as protein carbonylation was found to be an excellent approach for categorization.

These conclusions place FRAS assay as a useful step for surface reactivity measurement which itself, through grouping, is a critical step for nanomaterials hazard assessment.

\subsection{Classification with $\mathrm{Mn}_{2} \mathrm{O}_{3}$ in the context of DF4 nanogrouping}

The positive control of this assay $\left(\mathrm{Mn}_{2} \mathrm{O}_{3}\right)$ is particularly important since it allows the classification of the tested samples as "reactive" or "non-reactive" by delimiting a threshold based on its SBOD. In the workflow of DF4 nanogrouping, the measured sBOD of $\mathrm{Mn}_{2} \mathrm{O}_{3}$ was $192.2 \mathrm{nMTEU} / \mathrm{m}^{2}$. Above the limit 
of $10 \%$ of this sBOD, the nanomaterials are classified as reactive, which will classify them as group 4 , "active nanomaterials".

The classification as reactive or not is relative to the reactivity of a positive control. We can assume that the protocol used, the reagents used, and the grade of the biological matrix used can interfere in the measured BOD. Therefore, we would advise every team working on a FRAS assay to measure the BOD caused by $\mathrm{Mn}_{2} \mathrm{O}_{3}$ with the same protocol and the same chemicals used as for the measurement of the rest of the nanomaterials.

Moreover, note the importance of carefully choosing the right grade of $\mathrm{Mn}_{2} \mathrm{O}_{3}$. Consider choosing the nanoscale as the most relevant positive control for nanoparticles: its specific surface area must be close to the samples tested. In our case, we tested a microscale $\mathrm{Mn}_{2} \mathrm{O}_{3}$ (grade 1 ) and a nanoscale $\mathrm{Mn}_{2} \mathrm{O}_{3}$ (grade 2). These two samples caused variable but still comparable BOD (up to $110 \mathrm{mMTEU}$ for nanoscale $\mathrm{Mn}_{2} \mathrm{O}_{3}$ and $88 \mathrm{mMTEU}$ for micro-scale $\left.\mathrm{Mn}_{2} \mathrm{O}_{3}\right)$. However, their variation of SSA $\left(1.7 \mathrm{~m}^{2} / \mathrm{g} \mathrm{VS}\right.$ $20 \mathrm{~m}^{2} / \mathrm{g}$ ) automatically leads to an increased SBOD: for each square meter, the microscale grade of $\mathrm{Mn}_{2} \mathrm{O}_{3}$ seems to cause more BOD.

Overall, these two grades of $\mathrm{Mn}_{2} \mathrm{O}_{3}$ lead to a much higher sBOD than the one considered for classification in the context of DF4 nanogrouping. The closest $\mathrm{Mn}_{2} \mathrm{O}_{3}$ to the one used in the existing literature we could find is the grade $2\left(\mathrm{SSA}=18.7 \mathrm{~m}^{2} / \mathrm{g}\right.$ ) and led to a BOD of $103 \mathrm{mMTEU}$ and a SBOD of $550.9 \mathrm{nMTEU} / \mathrm{m}^{2}$ which is higher than $192.2 \mathrm{nMTEU} / \mathrm{m}^{2}$.

This major gap highlights the importance of considering the grade and source of chemicals used in assay, especially if a chemical is used as a control and/or for classification purposes.

In a grouping methodology, the FRAS assay needs to be standardized with a threshold splitting the materials as reactive or not. If we consider the threshold given by Arts et al., our CBs, amorphous silica and 7 of our GBMs (mostly rGOs) are classified as non-reactive while 15 GBMs can be classified as reactive.

Briefly, the decision-making framework of nanogrouping stands on three tiers, presented in Figure 4. 


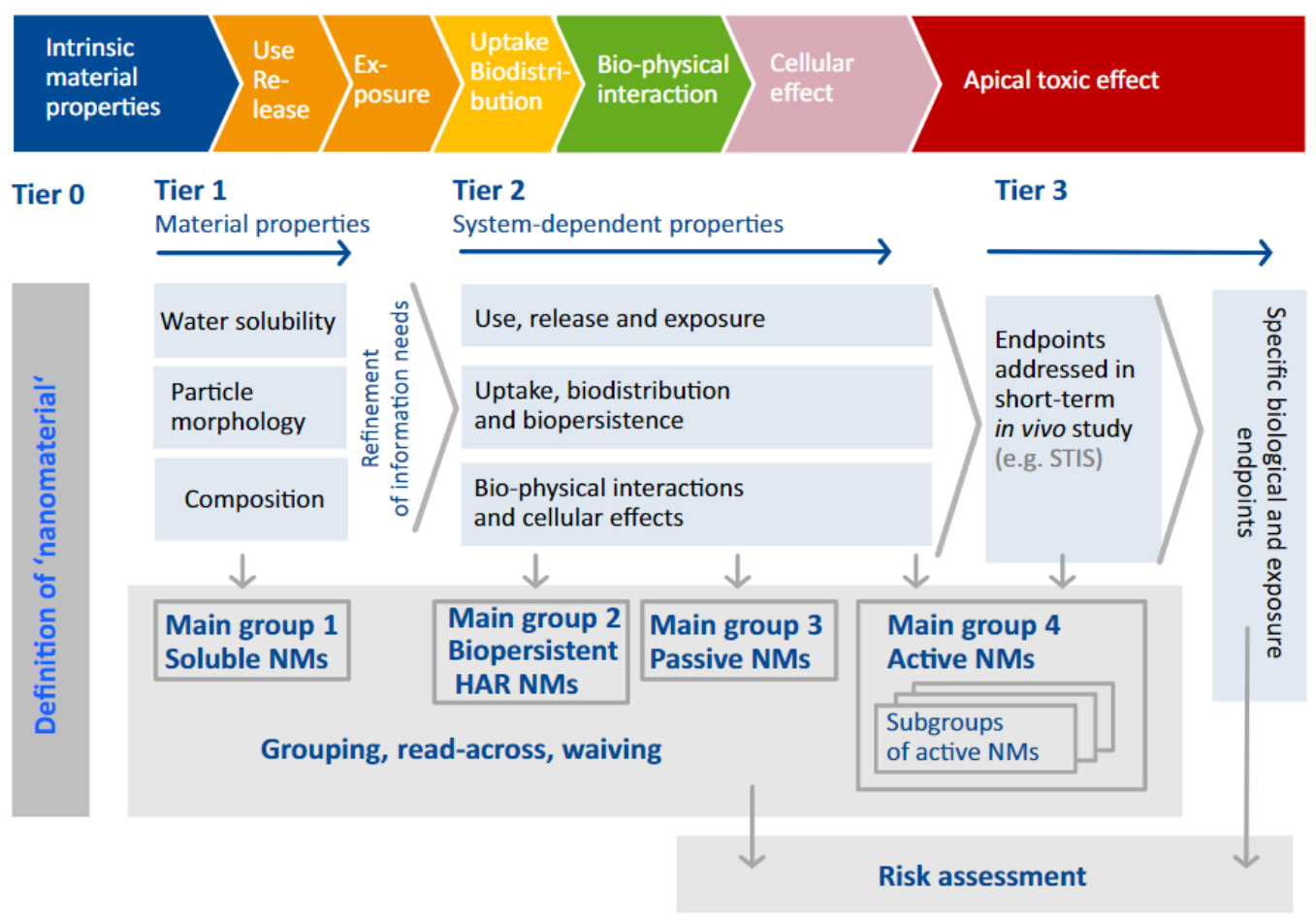

Figure 4: The decision-making framework for the grouping and testing of nanomaterials

(DF4nanoGrouping). Reproduced with permission.

The major grouping criteria are solubility, aspect ratio, surface reactivity (measured through FRAS assay) and cellular effect. The FRAS assay is hence only one step of a global grouping process.

For the first tiers, GBMs showed no solubility, excluding them from group 1 "soluble materials", GBMs do not present the properties of a HARP (high aspect ratio particle) and are not fibers, making the classification in group 2 "Biopersistent, HAR nanomaterials" irrelevant. In tier 2, surface reactivity could not be assessed due to the lack of knowledge about FRAS assay for graphene-based materials. In the case study presented by Arts et al., this data gap led to exclude GBMs from group 3 "Passive nanomaterials" and to classify them as group 4 "Active nanomaterials" by conservative default. The same graphite nanoplatelets as the one assessed in this case study were tested in another study and was classified as "passive" for cellular effects (Wiemann et al., 2016), yet still remained in group "Active nanomaterial", because of a lack of knowledge considering its FRAS effect. 
With our results, 7 GBMs showed a surface reactivity lower than the DF4 quantitative threshold (sBOD $<19.2 \mathrm{nTEU} / \mathrm{m}^{2}$ ), possibly allowing them to be classified in group 3 "passive nanomaterials".

With our measurements, we now know that some GBMs can be classified as non-reactive (concerning their surface reactivity). Therefore, performing the FRAS assay for GBMs can avoid data gaps which often lead to over classification.

\subsection{Feasibility and relevance of FRAS assay for graphene-based materials}

The assessment of biological oxidative damage (BOD) is an essential grouping criterion in the frame of DF4 nanogrouping, participating to the classification as "active" or "passive" nanomaterial, which will dramatically change its final risk assessment.

In addition, the FRAS assay is interesting as it can act as a screening test before heading to a complete toxicity assessment and does not require working in a cell culture lab. In a context of very high interest and demand for nanomaterials, including graphene-based materials (GBMs), there are often a great number of potential candidates to integrate into industrial process or to study further. A case-by-case approach for a complete toxicity assessment, including in vitro and in vivo testing, is often not relevant for very early stages of research and development. In this context, straightforward, cheap, and accessible methods such as FRAS assay can be a first step for a toxicity screening.

The protocol presented in supplementary data 2 enables to test 3 nanomaterials each day. We then needed a total of 3 to 4 weeks to perform the testing of 27 different samples and the calibration of the assay with the Trolox.

An important point we observed in our study is the saturation at approximately $100 \mathrm{mMTEU}$. In this regard, when testing very reactive samples such as GBMs, it might not be relevant to test concentrations higher than $10 \mathrm{~g} / \mathrm{L}$. If a very quick screening of a great number of samples is needed, one could consider studying only a $10 \mathrm{~g} / \mathrm{L}$ concentration (since it is the most commonly used dose in the literature and could allow easier inter-lab comparison) and having only one vial of blank each day. This way, it could be possible to test up to 11 nanomaterials in only one day. Another interesting 
approach would be to test one single surface dose of $1 \mathrm{~m}^{2} / \mathrm{L}$ and is described in a paper presenting nanoGRAVUR framework (Wohlleben et al., 2019). Lastly, for assessing the dose response of reactive materials, the FRAS assay can be performed using the same concentrations used for Trolox calibration (from $0.001 \mathrm{~g} / \mathrm{L}$ to $0.1 \mathrm{~g} / \mathrm{L}$, see section 2.4.1). This method allows a linear fit of the FRAS signal and avoids any saturation effect (Peijnenburg et al., 2020).

In this paper, we focused on GBMs. However, we also tested 2 carbon blacks with good results in terms of feasibility. This is an interesting information since these nanomaterials are often used at an important tonnage, carbon black being the most produced carbon-based nanostructure (Khodabakhshi, et al., 2020). Hence, these results can also indicate that the used FRAS protocol is adapted not only to GBMs, but also to carbon blacks.

Considering their mode of action involving oxidative stress and their very high specific surface area, assessing surface reactivity of GBMs is relevant. With our results, we showed that this assay was selective on a wide variety of samples. We obtained a FRAS response for almost all our tested GBMs, which can make us consider that their poor dispersibility was not an obstacle for this assay. Moreover, we highlighted a potential correlation between the results of early ROS production and FRAS assays: the GBMs that show an increased production of ROS are often the same ones that cause a high biological oxidative damage. These results can help us to consider FRAS as an interesting assay for nanoparticles with mode of action involving oxidative stress.

However, we can mention few limitations for our study. We aimed to study as many GBMs as possible, with different physico-chemical characteristics. However, we did not include GOs (graphene oxides). Since the FRAS assay was considered inappropriate for materials that interfered with the optical readout due to their black color and their lack of dispersibility, we focused on GBMs with a very low dispersibility, being mostly GNPs and rGOs. Knowing that GOs, due to their high oxidation state and their quite small lateral size (compared to our samples which can measure up to $30 \mu \mathrm{m}$ ), have been shown to have a better dispersibility than rGO (Konios et al., 2014) (Johnson et al., 2015), we can assume that if FRAS is feasible on very insoluble materials such as GNPs, it is probably feasible on quite 
soluble materials such as GOs. It might be yet necessary to test this assay on a few samples of GOs in the future to confirm this hypothesis.

\section{Conclusion}

As graphene based materials (GBMs) market share and global interest for application is growing, it became urgent to explore its potential toxicity. However, a case-by-case approach is often irrelevant in the earliest phases of the industrial process whereas quick and simple assays for early toxicity screening can be appropriate. These assays can also be integrated into a global process, such as grouping.

FRAS (ferric reducing ability of the serum) assay shows interesting assets: it is a simple assay, accessible and fast. Moreover, its reproducibility was previously studied, and its protocol have been optimized for nanomaterials. Yet, its feasibility on GBMs was questioned, due to the hydrophobicity of these samples.

We tested 25 samples, including 22 GBMs, 2 carbon blacks and 1 amorphous silica and measured their FRAS effect. We found various biological oxidative damage (BOD) caused by these samples. Overall, it appeared that FRAS was not only feasible on GBMs but represented a critical step for classification in the context of DF4 nanogrouping. FRAS assay cannot be considered as a single assay for measuring GBMs toxicity. However, it can be considered as a screening tool, or complement other toxicity assays.

\section{Funding}

This work was supported by Michelin.

\section{List of abbreviations}

- FRAS : Ferric reducing ability of the serum

- GBMs : Graphene-based materials

- DCFDA : Dichlorodihydrofluorescein Diacetate 
- EPR : Electron paramagnetic resonance

- ECHA : European chemicals agency

- FRAP : Ferric reducing ability of the plasma

- NM : Nanomaterials

- HBS : Human blood serum

- GNPs : Graphene nanoplatelets

- rGOs : Reduced graphene oxide

- GOs : Graphene oxide

- TEU : Trolox equivalent unit

- BOD : biological oxidative damage

- SBOD : Surface-based biological oxidative damage

- mBOD : Mass-based biological oxidative damage

- SSA : Specific surface area

- HARP : High aspect ratio particles

- ECETOC : European Centre for Ecotoxicology and Toxicology of Chemicals

- ROS : Reactive oxygen species

\section{References}

Achawi, S. et al. (2021) 'Graphene-Based Materials In Vitro Toxicity and Their Structure-Activity Relationships: A Systematic Literature Review', Chemical Research in Toxicology. doi: 10.1021/ACS.CHEMRESTOX.1C00243.

Arts, J. H. E. et al. (2015) 'A decision-making framework for the grouping and testing of nanomaterials (DF4nanoGrouping)', Regulatory Toxicology and Pharmacology, 71(2), pp. S1-S27. doi: 10.1016/j.yrtph.2015.03.007.

Arts, J. H. E. et al. (2016) 'Case studies putting the decision-making framework for the grouping and testing of nanomaterials (DF4nanoGrouping) into practice', Regulatory Toxicology and Pharmacology, 76, pp. 234-261. doi: 10.1016/j.yrtph.2015.11.020.

Arts, M. J. T. J. et al. (2004) 'Antioxidant capacity of reaction products limits the applicability of the Trolox Equivalent Antioxidant Capacity (TEAC) assay', Food and Chemical Toxicology, 42(1), pp. 45-49. doi: 10.1016/j.fct.2003.08.004. 
Bahl, A. et al. (2020) 'Nanomaterial categorization by surface reactivity: A case study comparing 35 materials with four different test methods', Nanolmpact, 19, p. 100234 doi: 10.1016/j.impact.2020.100234.

Benzie, I. F. F. and Strain, J. J. (1996) 'The ferric reducing ability of plasma (FRAP) as a measure of "antioxidant power": The FRAP assay", Analytical Biochemistry, 239(1), pp. 70-76. doi: 10.1006/abio.1996.0292.

$\mathrm{Bi}, \mathrm{X}$. and Westerhoff, P. (2019) 'Ferric reducing reactivity assay with theoretical kinetic modeling uncovers electron transfer schemes of metallic-nanoparticle-mediated redox in water solutions', Environmental Science: Nano, 6(6), pp. 1791-1798. doi: 10.1039/C9EN00258H.

Cecchini, S. and Fazio, F. (2020) 'Assessment of total antioxidant capacity in serum of heathy and stressed hens', Animals, 10(11), pp. 1-8. doi: 10.3390/ani10112019.

Dekkers, S. et al. (2016) 'Towards a nanospecific approach for risk assessment', Regulatory Toxicology and Pharmacology, 80, pp. 46-59. doi: 10.1016/j.yrtph.2016.05.037.

Delaval, M. et al. (2016) 'Assessment of the oxidative potential of nanoparticles by the cytochrome c assay: assay improvement and development of a high-throughput method to predict the toxicity of nanoparticles', Archives of Toxicology 2016 91:1, 91(1), pp. 163-177. doi: 10.1007/S00204-016-17013.

Gandon, A. et al. (2017) 'Surface reactivity measurements as required for grouping and read-across: An advanced FRAS protocol', in Journal of Physics: Conference Series. Institute of Physics Publishing, p. 12033. doi: $10.1088 / 1742-6596 / 838 / 1 / 012033$.

Gawron-Skarbek, A. et al. (2019) 'The influence of an eight-week cycloergometer-based cardiac rehabilitation on serum antioxidant status in men with coronary heart disease: A prospective study', Medicina (Lithuania), 55(4). doi: 10.3390/medicina55040111.

Giusti, A. et al. (2019) 'Nanomaterial grouping: Existing approaches and future recommendations', Nanolmpact. Elsevier B.V., p. 100182. doi: 10.1016/j.impact.2019.100182.

Hellack, B. et al. (2017) 'Analytical methods to assess the oxidative potential of nanoparticles: A 
review', Environmental Science: Nano. Royal Society of Chemistry, pp. 1920-1934. doi: 10.1039/c7en00346c.

Hsieh, S. F. et al. (2013) 'Mapping the biological oxidative damage of engineered nanomaterials', Small, 9(9-10), pp. 1853-1865. doi: 10.1002/smll.201201995.

Janer, G., Landsiedel, R. and Wohlleben, W. (2021) 'Rationale and decision rules behind the ECETOC NanoApp to support registration of sets of similar nanoforms within REACH', Nanotoxicology, 15(2), pp. 145-166. doi: 10.1080/17435390.2020.1842933.

Johnson, D. W., Dobson, B. P. and Coleman, K. S. (2015) 'A manufacturing perspective on graphene dispersions', Current Opinion in Colloid and Interface Science. Elsevier Ltd, pp. 367-382. doi: 10.1016/j.cocis.2015.11.004.

Karakoti, A. S., Hench, L. L. and Seal, S. (2006) 'The potential toxicity of nanomaterials - The role of surfaces', JOM. Springer, pp. 77-82. doi: 10.1007/s11837-006-0147-0.

Khodabakhshi, S., Fulvio, P. F. and Andreoli, E. (2020) 'Carbon black reborn: Structure and chemistry for renewable energy harnessing', Carbon, 162, pp. 604-649. doi: 10.1016/J.CARBON.2020.02.058.

Konios, D. et al. (2014) 'Dispersion behaviour of graphene oxide and reduced graphene oxide'. doi: 10.1016/j.jcis.2014.05.033

Lee, C. et al. (2008) 'Measurement of the Elastic Properties and Intrinsic Strength of Monolayer Graphene', Science, 321(5887), pp. 385-388. doi: 10.1126/science.1157996.

Magro, M. et al. (2018) 'The surface reactivity of iron oxide nanoparticles as a potential hazard for aquatic environments: A study on Daphnia magna adults and embryos', Scientific Reports, 8(1), p. 13017. doi: 10.1038/s41598-018-31483-6.

Mittal, S. et al. (2016) 'Physico-chemical properties based differential toxicity of graphene oxide/reduced graphene oxide in human lung cells mediated through oxidative stress', Scientific Reports, 6(1). doi: 10.1038/srep39548.

Novoselov, K. S. et al. (2012) 'A roadmap for graphene', Nature, 490(7419), pp. 192-200. doi: 10.1038/nature11458. 
Ou, L. et al. (2016) 'Toxicity of graphene-family nanoparticles: A general review of the origins and mechanisms', Particle and Fibre Toxicology. BioMed Central Ltd., pp. 1-24. doi: 10.1186/s12989-0160168-y.

Pal, A. K. et al. (2014) 'Screening for oxidative damage by engineered nanomaterials: A comparative evaluation of FRAS and DCFH', Journal of Nanoparticle Research, 16(2). doi: 10.1007/s11051-013-21673.

Peijnenburg, W. J. G. M. et al. (2020) 'A method to assess the relevance of nanomaterial dissolution during reactivity testing', Materials, 13(10), p. 2235. doi: 10.3390/MA13102235.

Pelin, M. et al. (2018) 'Graphene and graphene oxide induce ROS production in human HaCaT skin keratinocytes: The role of xanthine oxidase and NADH dehydrogenase', Nanoscale, 10(25), pp. 1182011830. doi: $10.1039 / c 8 n r 02933 d$.

Piątek-Guziewicz, A. et al. (2017) 'Ferric reducing ability of plasma and assessment of selected plasma antioxidants in adults with celiac disease', FOLIA MEDICA CRACOVIENSIA, 4, pp. 13-26.

Reiss, T., Hjelt, K. and Ferrari, A. C. (2019) 'Graphene is on track to deliver on its promises', Nature Nanotechnology 2019 14:10, 14(10), pp. 907-910. doi: 10.1038/s41565-019-0557-0.

Rogers, E. J., Bello, D. and Hsieh, S. F. (2008) ‘Oxidative stress as a screening metric of potential toxicity by nanoparticles and ariborne particulate matter', Inhalation Toxicology. Informa Healthcare, p. 895. doi: $10.1080 / 08958370802020828$.

Wohlleben, W. et al. (2019) 'The nanoGRAVUR framework to group (nano)materials for their occupational, consumer, environmental risks based on a harmonized set of material properties, applied to 34 case studies', Nanoscale, 11(38), pp. 17637-17654. doi: 10.1039/C9NR03306H.

Warheit, D. B., Reed, K. L. and Sayes, C. M. (2009) 'A role for nanoparticle surface reactivity in facilitating pulmonary toxicity and development of a base set of hazard assays as a component of nanoparticle risk management', Inhalation Toxicology, 21(SUPPL. 1), pp. 61-67. doi: 10.1080/08958370902942640.

Wiemann, M. et al. (2016) 'An in vitro alveolar macrophage assay for predicting the short-term 
inhalation toxicity of nanomaterials', Journal of Nanobiotechnology, 14(1). doi: 10.1186/s12951-0160164-2.

Zhang, H. et al. (2012) 'Use of Metal Oxide Nanoparticle Band Gap To Develop a Predictive Paradigm for Oxidative Stress and Acute Pulmonary Inflammation', ACS Nano, 6(5), pp. 4349-4368. doi: 10.1021/NN3010087. 
Supplementary data 1: Physicochemical characterization

\section{ICP Analysis}

\begin{tabular}{|c|c|c|c|c|c|c|c|c|c|c|c|c|c|c|c|c|c|c|c|c|c|c|c|}
\hline & \multicolumn{23}{|c|}{ ICP results (ppm) } \\
\hline & Al & B & $\mathrm{Ba}$ & $\mathrm{Ca}$ & Co & $\mathrm{Cr}$ & $\mathrm{Cu}$ & $\mathrm{Fe}$ & $\mathrm{K}$ & $\mathrm{Li}$ & $\mathrm{Mg}$ & $\mathrm{Mn}$ & Mo & $\mathrm{Na}$ & $\mathrm{Ni}$ & $S$ & $\mathrm{Si}$ & Sn & $\mathrm{Sr}$ & $\mathrm{Ti}$ & $\mathrm{V}$ & $\mathrm{Zn}$ & $\mathrm{Zr}$ \\
\hline GNP1 & 54 & 16 & 1 & 90 & 0 & 2 & 2 & 21 & 47 & 0 & 45 & 0 & 7 & 40 & 0 & 44 & 0 & 4 & 0 & 20 & 4 & 32 & 13 \\
\hline GNP2 & 430 & 92 & 3 & 538 & 0 & 1 & 5 & 1008 & 201 & 0 & 304 & 13 & 2 & 162 & 5 & 136 & 0 & 368 & 1 & 34 & 8 & 12 & 3 \\
\hline GNP3 & 434 & 97 & 5 & 147 & 0 & 26 & 21 & 589 & 708 & 0 & 182 & 6 & 19 & 420 & 22 & 421 & 0 & 32 & 2 & 108 & 33 & 8 & 13 \\
\hline GNP4 & 169 & 76 & 2 & 78 & 0 & 300 & 17 & 1015 & 403 & 0 & 29 & 32 & 15 & 162 & 81 & 2346 & 0 & 13 & 1 & 293 & 33 & 33 & 8 \\
\hline GNP5 & 113 & 58 & 1 & 40 & 0 & 275 & 7 & 1279 & 233 & 0 & 37 & 32 & 9 & 168 & 136 & 1472 & 0 & 14 & 0 & 5 & 9 & 23 & 5 \\
\hline GNP6 & 108 & 115 & 1 & 33 & 0 & 350 & 9 & 1594 & 196 & 0 & 37 & 45 & 9 & 188 & 175 & 1910 & 0 & 9 & 0 & 33 & 9 & 12 & 4 \\
\hline GNP7 & 87 & 45 & 1 & 20 & 0 & 222 & 5 & 1044 & 265 & 0 & 38 & 42 & 5 & 197 & 91 & 6464 & 0 & 9 & 0 & 138 & 12 & 13 & 2 \\
\hline GNP8 & 118 & 21 & 1 & 42 & 0 & 201 & 9 & 1068 & 223 & 0 & 80 & 29 & 3 & 135 & 90 & 12114 & 0 & 10 & 0 & 70 & 6 & 15 & 4 \\
\hline GNP9 & 117 & 61 & 1 & 122 & 0 & 231 & 5 & 1224 & 299 & 0 & 61 & 34 & 4 & 145 & 100 & 9431 & 0 & 13 & 0 & 34 & 7 & 23 & 3 \\
\hline GNP10 & 86 & 5 & 1 & 63 & 0 & 214 & 4 & 1270 & 173 & 0 & 36 & 42 & 4 & 319 & 100 & 1420 & 0 & 17 & 0 & 8 & 7 & 13 & 2 \\
\hline GNP11 & 184 & 16 & 1 & 83 & 0 & 267 & 8 & 1149 & 134 & 0 & 97 & 52 & 4 & 173 & 101 & 2085 & 0 & 6 & 0 & 5 & 4 & 22 & 1 \\
\hline GNP12 & 197 & 42 & 3 & 784 & 0 & 3 & 154 & 5980 & 189 & 0 & 207 & 29 & 4 & 73 & 32 & 3727 & 0 & 9 & 2 & 9 & 6 & 17 & 2 \\
\hline GNP13 & 119 & 72 & 1 & 65 & 0 & 0 & 0 & 524 & 137 & 28 & 4 & 5 & 0 & 76 & 8 & 20 & 0 & 7 & 1 & 16 & 127 & 22 & 2 \\
\hline GNP14 & 85 & 41 & 4 & 235 & 0 & 7 & 8 & 2373 & 114 & 0 & 28 & 19 & 4 & 47 & 6 & 28 & 0 & 9 & 2 & 23 & 11 & 30 & 1 \\
\hline GNP15 & 87 & 54 & 12 & 203 & 0 & 0 & 0 & 1173 & 121 & 0 & 24 & 6 & 3 & 46 & 2 & 44 & 0 & 9 & 5 & 35 & 7 & 16 & 3 \\
\hline rGO3 & 236 & 76 & 1 & 135 & 0 & 54 & 3 & 252 & 393 & 0 & 30 & 2058 & 3 & 98 & 24 & 156 & 0 & 307 & 1 & 3 & 5 & 221 & 2 \\
\hline rGO4 & 279 & 155 & 4 & 1315 & 0 & 7 & 0 & 151 & 1907 & 0 & 1257 & 299 & 66 & 4518 & 77 & 14679 & 0 & 14 & 14 & 3 & 11 & 599 & 7 \\
\hline rGO5 & 269 & 230 & 2 & 1661 & 0 & 64 & 0 & 215 & 1035 & 0 & 1369 & 431 & 15 & 1618 & 34 & 2819 & 0 & 196 & 15 & 68 & 12 & 55 & 56 \\
\hline rGO6 & 372 & 212 & 10 & 668 & 0 & 13 & 0 & 557 & 2403 & 0 & 585 & 1479 & 169 & 3089 & 658 & 4440 & 0 & 17 & 7 & 6 & 11 & 146 & 3 \\
\hline rGO7 & 235 & 239 & 3 & 1416 & 0 & 0 & 0 & 95 & 1866 & 0 & 1360 & 457 & 111 & 5893 & 53 & 9714 & 0 & 15 & 14 & 17 & 7 & 35 & 3 \\
\hline rGO8 & 463 & 426 & 3 & 338 & 0 & 34 & 9 & 224 & 1512 & 0 & 209 & 1907 & 27 & 862 & 36 & 5141 & 0 & 36 & 3 & 567 & 52 & 34 & 12 \\
\hline rGO9 & 402 & 165 & 2 & 256 & 0 & 23 & 0 & 215 & 1505 & 0 & 235 & 1847 & 23 & 744 & 38 & 761 & 0 & 73 & 2 & 676 & 51 & 66 & 7 \\
\hline Amorphous Silica & 3223 & 43 & 19 & 388 & 0 & 0 & 0 & 62 & 90 & 0 & 49 & 1 & 2 & 7669 & 0 & 3356 & 0 & 5 & 1 & 24 & 2 & 7 & 6 \\
\hline CB1 & 136 & 15 & 1 & 411 & 0 & 2 & 0 & 66 & 221 & 0 & 152 & 1 & 0 & 667 & 1 & 10799 & 0 & 5 & 5 & 2 & 2 & 29 & 0 \\
\hline $\mathrm{CB} 2$ & 92 & 11 & 1 & 286 & 0 & 1 & 0 & 46 & 216 & 0 & 97 & 1 & 0 & 101 & 1 & 9875 & 0 & 7 & 1 & 3 & 0 & 20 & 0 \\
\hline
\end{tabular}




\begin{tabular}{|c|c|c|c|c|c|}
\hline & \multicolumn{5}{|c|}{ XPS (atomic \%) } \\
\cline { 2 - 6 } & $\mathrm{C}$ & $\mathrm{O}$ & $\mathrm{N}$ & $\mathrm{S}$ & $\mathrm{Si}$ \\
\hline GNP1 & 96,8 & 3,2 & 0,0 & 0,0 & 0,0 \\
\hline GNP2 & 93,7 & 6,3 & 0,0 & 0,0 & 0,0 \\
\hline GNP3 & 92,4 & 7,6 & 0,0 & 0,0 & 0,0 \\
\hline GNP4 & 95,7 & 4,3 & 0,0 & 0,0 & 0,0 \\
\hline GNP5 & 96,7 & 3,3 & 0,0 & 0,0 & 0,0 \\
\hline GNP6 & 97,3 & 2,6 & 0,0 & 0,1 & 0,0 \\
\hline GNP7 & 95,4 & 4,2 & 0,0 & 0,4 & 0,0 \\
\hline GNP8 & 93,2 & 5,9 & 0,5 & 0,4 & 0,0 \\
\hline GNP9 & 93,2 & 5,7 & 0,7 & 0,3 & 0,0 \\
\hline GNP10 & 97,9 & 2,1 & 0,0 & 0,0 & 0,0 \\
\hline GNP11 & 97,5 & 2,5 & 0,0 & 0,0 & 0,0 \\
\hline GNP12 & 93,2 & 6,1 & 0,8 & 0,0 & 0,0 \\
\hline GNP13 & 95,6 & 4,4 & 0,0 & 0,0 & 0,0 \\
\hline GNP14 & 94,9 & 4,5 & 0,6 & 0,0 & 0,0 \\
\hline GNP15 & 96,0 & 3,5 & 0,5 & 0,0 & 0,0 \\
\hline rGO3 & 88,1 & 11,9 & 0,0 & 0,0 & 0,0 \\
\hline rGO4 & 91,7 & 7,2 & 0,0 & 1,0 & 0,0 \\
\hline rGO5 & 96,6 & 2,7 & 0,6 & 0,2 & 0,0 \\
\hline rGO6 & 84,1 & 15,9 & 0,0 & 0,0 & 0,0 \\
\hline rGO7 & 92,6 & 6,7 & 0,0 & 0,7 & 0,0 \\
\hline rGO8 & 82,8 & 17,2 & 0,0 & 0,0 & 0,0 \\
\hline rGO9 & 95,2 & 2,6 & 2,2 & 0,0 & 0,0 \\
\hline Amorphous Silica & 96,9 & 2,6 & 0,0 & 0,5 & 0,0 \\
\hline CB1 & 97,2 & 2,3 & 0,0 & 0,5 & 0,0 \\
\hline CB2 & 3,6 & 70,0 & 0,0 & 0,0 & 26,4 \\
\hline
\end{tabular}

\section{RAMAN spectra}

\section{rGO spectrum}
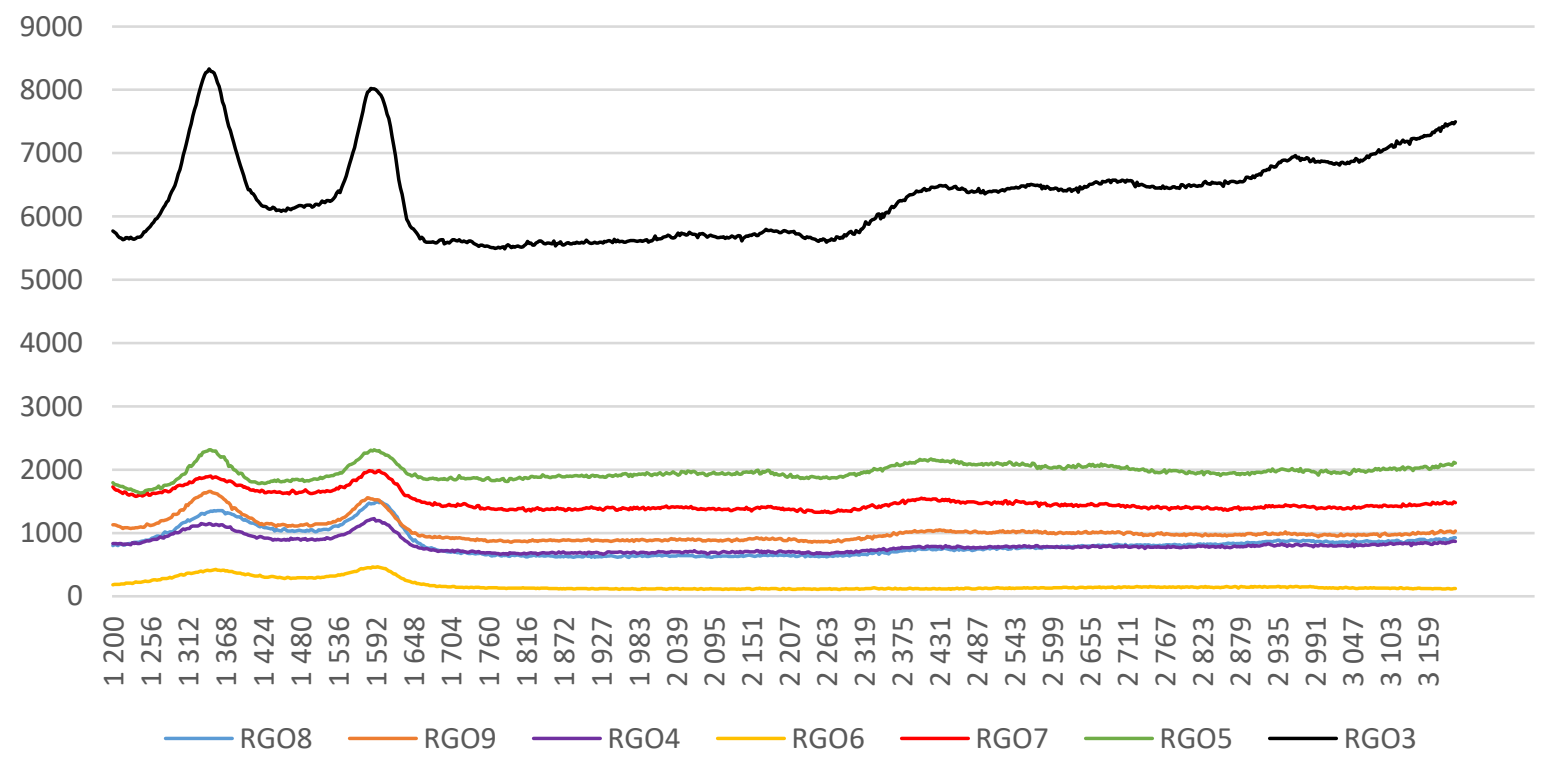


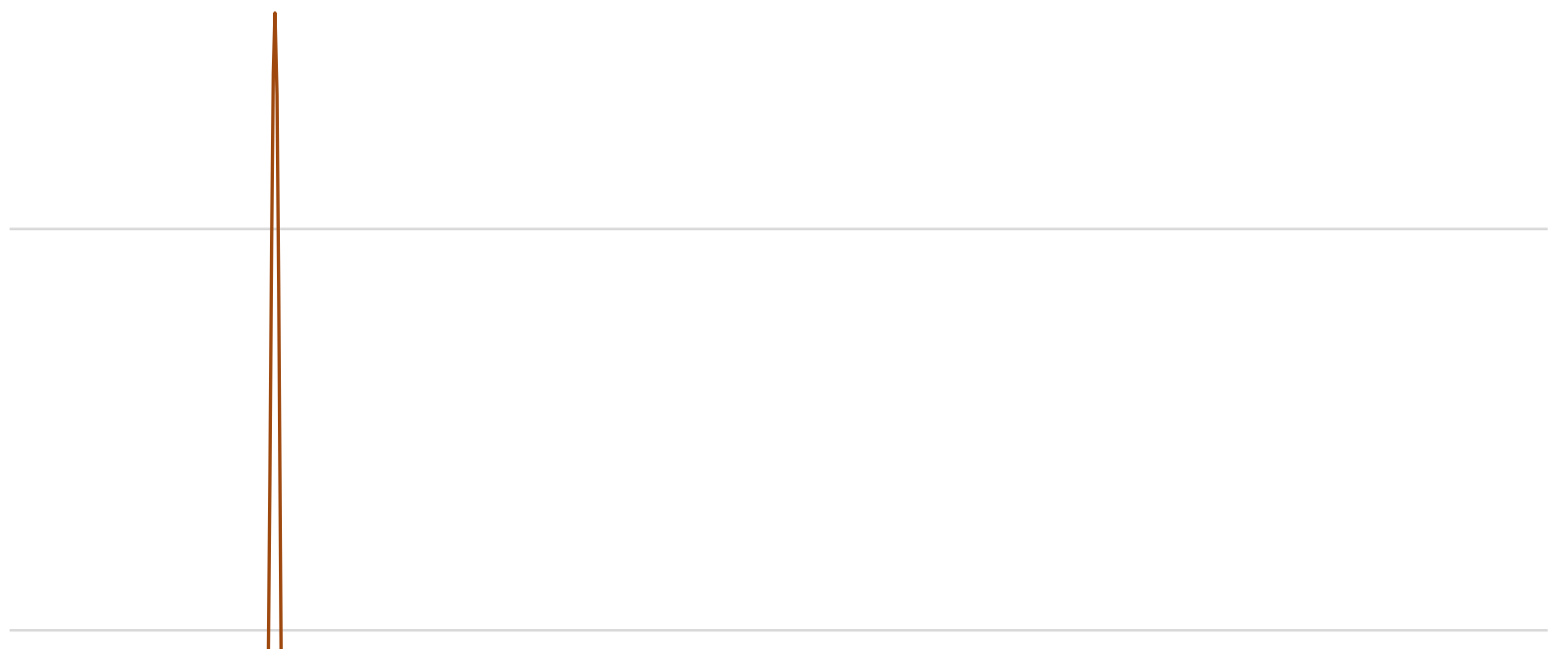

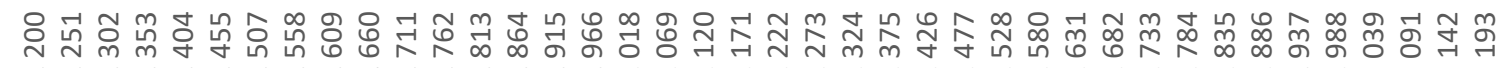

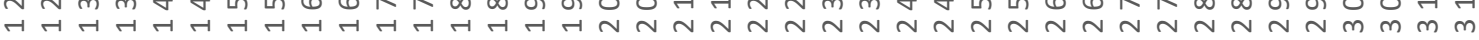

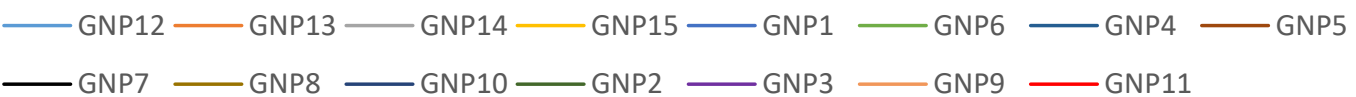


Supplementary data 2: Presentation of the protocol and descriptive figure.

\begin{tabular}{|c|c|c|c|c|c|}
\hline Step & $\begin{array}{c}\text { Time } \\
\text { needed }\end{array}$ & $\begin{array}{l}\text { Equipment } \\
\text { needed }\end{array}$ & $\begin{array}{l}\text { Chemicals } \\
\text { needed }\end{array}$ & $\begin{array}{l}\text { Special cautions } \\
\text { and comments }\end{array}$ & Process \\
\hline \multirow[t]{2}{*}{$\begin{array}{l}\text { Step } 1 \text { : Weight } \\
\text { the powders }\end{array}$} & \multirow[t]{2}{*}{$\begin{array}{l}45 \\
\text { minutes }\end{array}$} & $\begin{array}{l}\text { Ultraprecision } \\
\text { Balance }\end{array}$ & \multirow[t]{2}{*}{$\begin{array}{l}\text { Powders of } \\
\text { nanomaterials } \\
\text { ( } 3 \text { different } \\
\text { nanomaterials } \\
\text { can be tested } \\
\text { in one day) }\end{array}$} & \multirow{2}{*}{$\begin{array}{l}\text { Nanopowders } \\
\text { can be very } \\
\text { pulverulent: use } \\
\text { mask, } \\
\text { protection and if } \\
\text { possible work in } \\
\text { a special } \\
\text { designed lab } \\
\text { This step can be } \\
\text { done the day } \\
\text { before the next } \\
\text { steps. }\end{array}$} & \multirow[t]{2}{*}{$\begin{array}{l}\text { Weight } 7.5,15 \text { and } 30 \mathrm{mg} \text { of } \\
\text { each nanomaterials in a glass } \\
\text { centrifuge tube. For each } \\
\text { nanomaterial tested, one glass } \\
\text { centrifuge tube must remain } \\
\text { empty (blank) }\end{array}$} \\
\hline & & $\begin{array}{l}\text { Centrifuge } \\
\text { Glass tubes }\end{array}$ & & & \\
\hline $\begin{array}{c}\text { Step 2: } \\
\text { Unfreeze the } \\
\text { human blood } \\
\text { serum }\end{array}$ & $\begin{array}{l}15 \\
\text { minutes }\end{array}$ & Heating Bath & $\begin{array}{l}\text { Frozen } \\
\text { Human Blood } \\
\text { serum, HIV } \\
\text { tested, } \\
\text { aliquoted in } \\
7 \mathrm{~mL} \text { samples }\end{array}$ & $\begin{array}{l}\text { If a heating bath } \\
\text { is not available, } \\
\text { this step can be } \\
\text { done at room } \\
\text { temperature : } \\
\text { plan } \\
\text { approximately } \\
40 \text { minutes for } \\
7 \text { mL aliqots. }\end{array}$ & $\begin{array}{l}\text { Thaw } 7 \mathrm{~mL} \text { for each } \\
\text { nanomaterial tested ( } 3 \text { vials of } 7 \\
\mathrm{~mL} \text { are thawed for a day where } \\
3 \text { nanomaterials are being } \\
\text { tested). }\end{array}$ \\
\hline \multirow[t]{2}{*}{$\begin{array}{c}\text { Step } 3 \text { : Adding } \\
\text { HBS to } \\
\text { powders }\end{array}$} & \multirow[t]{2}{*}{$\begin{array}{l}15 \\
\text { minutes }\end{array}$} & $\begin{array}{l}\text { Glass Pasteur } \\
\text { pipette }\end{array}$ & $\begin{array}{l}\text { Thawed } \\
\text { Human Blood } \\
\text { serum. }\end{array}$ & \multirow{2}{*}{$\begin{array}{l}\text { Nano powders } \\
\text { can be very } \\
\text { pulverulent : use } \\
\text { mask, } \\
\text { protection and if } \\
\text { possible work in } \\
\text { a special } \\
\text { designed lab }\end{array}$} & \multirow[t]{2}{*}{$\begin{array}{l}\text { Weight } 1.5 \mathrm{~g} \text { of thawed Human } \\
\text { Blood serum to each tube } \\
\text { containing powders, and to the } \\
\text { empty one (blank) }\end{array}$} \\
\hline & & $\begin{array}{l}\text { Ultraprecision } \\
\text { Balance }\end{array}$ & $\begin{array}{l}\text { Powder of } \\
\text { nanomaterials }\end{array}$ & & \\
\hline \multicolumn{6}{|c|}{$\begin{array}{l}\text { To this stage, for the testing of } 3 \text { nanomaterials in one day (recommended), } 12 \text { glass centrifuges tubes should be } \\
\text { used. Each nanomaterial groups } 4 \text { tubes: one containing only HBS (blank, CO), one containing a mix of HBS and } \\
\text { powders at } 5 \mathrm{~g} / \mathrm{L}(\mathrm{C} 5) \text {, one containing a mix of HBS and powders at } 10 \mathrm{~g} / \mathrm{L}(\mathrm{C10}) \text {, one containing a mix of HBS and } \\
\text { powders at } 20 \mathrm{~g} / \mathrm{L}(\mathrm{C2O}),\end{array}$} \\
\hline \multirow[t]{2}{*}{$\begin{array}{l}\text { Step } 4: \text { Vortex } \\
\text { and sonicate } \\
\text { the mix HBS - } \\
\quad \text { powder }\end{array}$} & \multirow[t]{2}{*}{$\begin{array}{l}15 \\
\text { minutes }\end{array}$} & $\begin{array}{l}\text { Sonicator } \\
\text { Bath }\end{array}$ & \multirow[t]{2}{*}{$\begin{array}{l}\text { Mix human } \\
\text { blood serum - } \\
\text { powders and } \\
\text { Human blood } \\
\text { serum alone } \\
\text { (blank) }\end{array}$} & \multirow{2}{*}{$\begin{array}{l}\text { Do not forget to } \\
\text { vortex and } \\
\text { sonicate the } \\
\text { blanks the same } \\
\text { way you did } \\
\text { with the mix } \\
\text { Human Blood } \\
\text { serum and } \\
\text { powders. }\end{array}$} & \multirow[t]{2}{*}{$\begin{array}{l}\text { For each vial : } \\
\text { Vortex } 30 \text { seconds ( } 3000 \mathrm{rpm} \text { ), } \\
20^{\circ} \mathrm{C} \\
\text { Sonicate in a sonicate bath } 10 \\
\text { minutes, } 130 \mathrm{~Hz}, 20^{\circ} \mathrm{C}\end{array}$} \\
\hline & & Vortex & & & \\
\hline
\end{tabular}




\begin{tabular}{|c|c|c|c|c|c|}
\hline $\begin{array}{c}\text { Step } 5 \text { : } \\
\text { Incubation }\end{array}$ & 3 hours & $\begin{array}{l}\text { Thermo mixer } \\
\text { (or incubator } \\
\text { and agitator) }\end{array}$ & $\begin{array}{l}\text { Mix human } \\
\text { blood serum - } \\
\text { powders and } \\
\text { Human blood } \\
\text { serum alone } \\
\text { (blank), } \\
\text { properly } \\
\text { vortexed and } \\
\text { sonicated }\end{array}$ & $\begin{array}{l}\text { If a } \\
\text { Thermomixer is } \\
\text { no available, } \\
\text { place an agitator } \\
\text { in an incubator: } \\
\text { Avoiding direct } \\
\text { light, } \\
\text { maintaining the } \\
\text { samples at } 37^{\circ} \mathrm{C} \\
\text { and a gentle } \\
\text { agitation for } 3 \\
\text { hours is critical. }\end{array}$ & $\begin{array}{l}\text { Agitate at around } 450 \mathrm{rpm} \text { for } 3 \\
\text { hours, at } 37^{\circ} \mathrm{C} \text {, avoiding direct } \\
\text { light dark, all the samples and } \\
\text { the blanks. }\end{array}$ \\
\hline \multirow[t]{6}{*}{$\begin{array}{l}\text { Step } 6: \\
\text { Preparation of } \\
\text { the FRAS } \\
\text { reagent }\end{array}$} & \multirow[t]{6}{*}{1 hour } & \multirow[t]{3}{*}{$\begin{array}{l}\text { Ultraprecision } \\
\text { balance }\end{array}$} & $\begin{array}{l}\text { Deionized } \\
\text { water }\end{array}$ & \multirow{6}{*}{$\begin{array}{l}\text { As the following } \\
\text { solutions cannot } \\
\text { be stored, they } \\
\text { have to be } \\
\text { prepared freshly } \\
\text { before every } \\
\text { experiment. } \\
\text { Preparing S1, S2 } \\
\text { and S3 can be } \\
\text { done with } \\
\text { plastic } \\
\text { elements. } \\
\text { However, when } \\
\text { mixed, the final } \\
\text { FRAS regents } \\
\text { must be } \\
\text { exposed to glass } \\
\text { elements only, } \\
\text { and have to be } \\
\text { kept away from } \\
\text { direct light. }\end{array}$} & \multirow{6}{*}{$\begin{array}{l}\text { Prepare } \mathbf{S 1} \text { : } \\
\text { - Weigh } 0.0946 \mathrm{~g} \text { of TPTZ in a } \\
30 \mathrm{~mL} \text { glass container. } \\
\text { - Add } 15 \mathrm{~g} \text { of distilled water. } \\
\text { - Add } 1.2 \mathrm{~mL} \text { of } \mathrm{HCl} 1 \mathrm{M} \\
\text { - Add distilled water to achieve } \\
\text { a total of } 30 \mathrm{~g} \text {. } \\
\text { - Put } \mathrm{S} 1 \text { to an ultrasonication } \\
\text { bath and sonicate for } 30 \\
\text { minutes with maximum power } \\
\text { at room temperature. } \\
\text { Prepare } \mathrm{S2} \text { : } \\
\text { - Weigh } 0.2021 \mathrm{~g} \text { of sodium } \\
\text { acetic trihydrate in a } 100 \mathrm{~mL} \\
\text { glass container. } \\
\text { - Add } 50 \mathrm{~g} \text { of distilled water. } \\
\text { - Add } 1.060 \mathrm{~mL} \text { of glacial acetic. } \\
\text { - Add distilled water to achieve } \\
\text { a total of } 100 \mathrm{~g} \text {. } \\
\text { Prepare } \mathrm{S3} \text { : } \\
\text { - Weigh } 0.1635 \mathrm{~g} \text { of FeCl3.6H2O } \\
\text { in a } 30 \mathrm{~mL} \text { glass container. } \\
\text { - Add distilled water to achieve } \\
\text { a total of } 30 \mathrm{~g} \text {. } \\
\text { Prepare FRAS reagent: } \\
\text { - Mix } \mathrm{S} 1, \mathrm{~S} 2 \text { and } \mathrm{S} 3 \text { : Add } 7 \mathrm{~g} \text { of } \\
\mathrm{S} 1,7 \mathrm{~g} \text { of } \mathrm{S} 3 \text { and } 70 \mathrm{~g} \text { of } \mathrm{S} 2 \mathrm{in} \text { a } \\
100 \mathrm{~mL} \text { glass container. } \\
\text { - Store the FRAS reagent in } \\
\text { gentle agitation ( } 300 \mathrm{rpm),} \mathrm{in} \\
\text { the dark, room temperature, } \\
\text { until use }\end{array}$} \\
\hline & & & $\begin{array}{l}\text { TPTZ (2,4,6- } \\
\text { Tri(2-pyridyl)- } \\
\text { 1,3,5-triazine) }\end{array}$ & & \\
\hline & & & $\mathrm{FeCl}_{3.6 \mathrm{H} 2 \mathrm{O}}$ & & \\
\hline & & \multirow[t]{2}{*}{ Agitator } & glacial acetic & & \\
\hline & & & $\begin{array}{l}\text { sodium acetic } \\
\text { trihydrate }\end{array}$ & & \\
\hline & & $\begin{array}{l}\text { Sonicator } \\
\text { Bath }\end{array}$ & $1 \mathrm{M} \mathrm{HCl}$ & & \\
\hline
\end{tabular}




\begin{tabular}{|c|c|c|c|c|c|}
\hline $\begin{array}{l}\text { Step } 7: \text { Label } \\
\text { the reaction } \\
\text { vials and the } \\
\text { supernatant } \\
\text { vials }\end{array}$ & $\begin{array}{l}15 \\
\text { minutes }\end{array}$ & $\begin{array}{l}3610 \mathrm{~mL} \text { glass } \\
\text { reaction vial } \\
\text { (12 for each } \\
\text { nanomaterial } \\
\text { tested) } \\
1210 \mathrm{~mL} \text { glass } \\
\text { supernatant } \\
\text { vials ( } 4 \text { for } \\
\text { each } \\
\text { nanomaterial } \\
\text { tested) }\end{array}$ & & $\begin{array}{l}\text { Consider using } \\
\text { different colors } \\
\text { for labelling } \\
\text { supernatant and } \\
\text { reaction vials }\end{array}$ & $\begin{array}{l}\text { Label the reaction glass vials as } \\
\text { so : Nanomaterial code - } \\
\text { concentration - triplicate } \\
\text { number } \\
\text { For instance, label AC5, AC5' } \\
\text { and AC5" for the reaction vials } \\
\text { receiving the three triplicates of } \\
\text { a } 5 \mathrm{~g} / \mathrm{L} \text { concentration of a } \\
\text { nanomaterial A. } \\
\text { Label the supernatant vials as } \\
\text { so : Nanomaterial code - } \\
\text { concentration. } \\
\text { See supplementary figure } 3 \text { for } \\
\text { labelling vials }\end{array}$ \\
\hline $\begin{array}{c}\text { Step 8: } \\
\text { Centrifugation* }\end{array}$ & $\begin{array}{l}2 \text { hours } \\
30 \\
\text { minutes }\end{array}$ & Centrifuge & $\begin{array}{l}\text { Mix human } \\
\text { blood serum - } \\
\text { powders and } \\
\text { Human blood } \\
\text { serum alone } \\
\text { (blank), } \\
\text { properly } \\
\text { vortexed and } \\
\text { sonicated and } \\
\text { incubated }\end{array}$ & & $\begin{array}{l}\text { Centrifuge at } 4800 \mathrm{rpm} \text { for } 150 \\
\text { minutes, at } 20^{\circ} \mathrm{C} \text {. }\end{array}$ \\
\hline $\begin{array}{l}\text { Step } 9: \text { Fill } \\
\text { every reaction } \\
\text { vial with the } \\
\text { FRAS reagent }\end{array}$ & $\begin{array}{l}30 \\
\text { minutes }\end{array}$ & $\begin{array}{l}2 \mathrm{~mL} \text { glass } \\
\text { pipette } \\
3610 \mathrm{~mL} \\
\text { reaction glass } \\
\text { vials (12 for } \\
\text { each } \\
\text { nanomaterial } \\
\text { tested) }\end{array}$ & $\begin{array}{l}\text { FRAS reagent, } \\
\text { freshly } \\
\text { prepared (the } \\
\text { day of the } \\
\text { experiment) }\end{array}$ & $\begin{array}{l}\text { If } 2 \mathrm{~mL} \text { glass } \\
\text { pipette is not } \\
\text { available, you } \\
\text { can use up to } 5 \\
\mathrm{~mL} \text { glass pipette } \\
\text { for maximal } \\
\text { precision. } \\
\text { If you don't have } \\
\text { a graduated } \\
\text { glass pipette, } \\
\text { you can use } \\
\text { Pasteur Pipette } \\
\text { and weight } 2 \\
\text { grams of FRAS } \\
\text { reagent, using } \\
\text { an } \\
\text { ultraprecision } \\
\text { balance. } \\
\text { Use only glass } \\
\text { element, and } \\
\text { avoid direct light } \\
\text { contact for this } \\
\text { step. }\end{array}$ & $\begin{array}{l}\text { Distribute } 2 \mathrm{~mL} \text { of FRAS reagent } \\
\text { in each of the } 36 \text { reaction glass } \\
\text { vials. }\end{array}$ \\
\hline
\end{tabular}




\begin{tabular}{|c|c|c|c|c|c|}
\hline $\begin{array}{c}\text { Step 10: } \\
\text { Collect the } \\
\text { supernatant } *\end{array}$ & $\begin{array}{l}15 \\
\text { minutes }\end{array}$ & $\begin{array}{l}\text { Pasteur } \\
\text { pipette } \\
\text { Labelled } \\
\text { supernatant } \\
\text { glass vials }\end{array}$ & $\begin{array}{l}\text { Mix human } \\
\text { blood serum - } \\
\text { powders and } \\
\text { Human blood } \\
\text { serum alone } \\
\text { (blank), } \\
\text { properly } \\
\text { vortexed, } \\
\text { sonicated, } \\
\text { incubated and } \\
\text { centrifugated. }\end{array}$ & $\begin{array}{l}\text { Discard the first } \\
\text { and the last } \\
\text { drop to avoid } \\
\text { any trace of } \\
\text { nanoparticles } \\
\text { powders in the } \\
\text { supernatant. }\end{array}$ & $\begin{array}{l}\text { Collect the supernatant of each } \\
\text { vial. } \\
\text { For nanoparticles of very low } \\
\text { density, it might be necessary to } \\
\text { add a filtration step : see } \\
\text { section } 3 \text { of Material and } \\
\text { Methods of the paper. }\end{array}$ \\
\hline \multirow[t]{2}{*}{$\begin{array}{l}\text { Step } 11: \text { FRAS } \\
\text { reaction }\end{array}$} & \multirow[t]{2}{*}{1 hour } & \multirow{2}{*}{$\begin{array}{l}\text { Glass Pasteur } \\
\text { pipette } \\
36 \mathrm{~mL} \\
\text { reaction glass } \\
\text { vials } \\
1 \mathrm{~mL} \\
\text { graduated } \\
\text { glass pipette } \\
\text { Agitator }\end{array}$} & FRAS reagent & \multirow{2}{*}{$\begin{array}{l}\text { If possible, use } \\
\text { glass tips } \\
\text { adapted to a } \\
\text { pipetor to have } \\
\text { a better } \\
\text { efficiency and } \\
\text { precision. }\end{array}$} & \multirow{2}{*}{$\begin{array}{l}\text { Every } 1 \text { minute and } 30 \text { seconds, } \\
\text { add } 100 \mu \mathrm{L} \text { of supernatant in } \\
\text { the FRAS reagent. Let the mix } \\
\text { FRAS reagent }+ \text { supernatant } \\
\text { incubate for } 1 \text { hour precisely, } \\
\text { while agitating at } 400 \mathrm{rpm} \text {, and } \\
\text { away from direct light. }\end{array}$} \\
\hline & & & $\begin{array}{l}\text { Supernatant } \\
\text { of the mix } \\
\text { human blood } \\
\text { serum - } \\
\text { powders }\end{array}$ & & \\
\hline $\begin{array}{c}\text { Step 12: } \\
\text { Absorption } \\
\text { measurement }\end{array}$ & 1 hour & $\begin{array}{l}\text { Quartz } \\
\text { cuvette } \\
\text { Spectrometer } \\
\text { Glass Pasteur } \\
\text { Pipette }\end{array}$ & $\begin{array}{l}\text { Mix FRAS } \\
\text { regent and } \\
\text { supernatant } \\
\text { of HBS }\end{array}$ & $\begin{array}{l}\text { An automatic } \\
\text { linear cell } \\
\text { changer can be } \\
\text { useful to respect } \\
\text { the } 60 \text { minutes } \\
\text { timing more } \\
\text { easily. }\end{array}$ & $\begin{array}{l}\text { At precisely } 60 \text { minutes of } \\
\text { incubation, measure the } \\
\text { absorbance of the sample. } \\
\text { Immediately after the } \\
\text { measurements, rinse the quartz } \\
\text { cuvette with distilled water, } \\
\text { ensure you have no water left } \\
\text { (suck in the inside of the } \\
\text { cuvette with a Pasteur pipette) } \\
\text { and fill it with the next sample. }\end{array}$ \\
\hline
\end{tabular}

\section{Modifications compared to the protocol presented by Gandon et al.}

The steps are indicated with an asterisk in the table above.

We wanted to have an insight of a potential dose-effect relationship without going through a complete screening: we then worked on 3 different exposure concentrations $(5,10$ and $20 \mathrm{~g} / \mathrm{L}$ instead of 0.75 , $2,5.5,15$, and $40 \mathrm{~g} / \mathrm{L}$ described by Gandon et al.). The maximum power of our centrifuge was 4,690 rpm (instead of 11,900rpm) which was efficient enough to separate graphene-based materials powders from HBS. The use of glass components is critical for many steps as the use of plastic was found to influence the assay outcome by Gandon et al., so we chose to work with glass centrifugation tubes. Lastly, we did not have an automatic cell changer in our UV/Vis spectrometer. We used the same quartz cell that we filled manually and adapted our schedule to strictly respect the required time of reaction of 60 minutes. 
1. Prepare blank human blood serum (CO) and human blood serum nanomaterial solutions (C5, C10, C20)

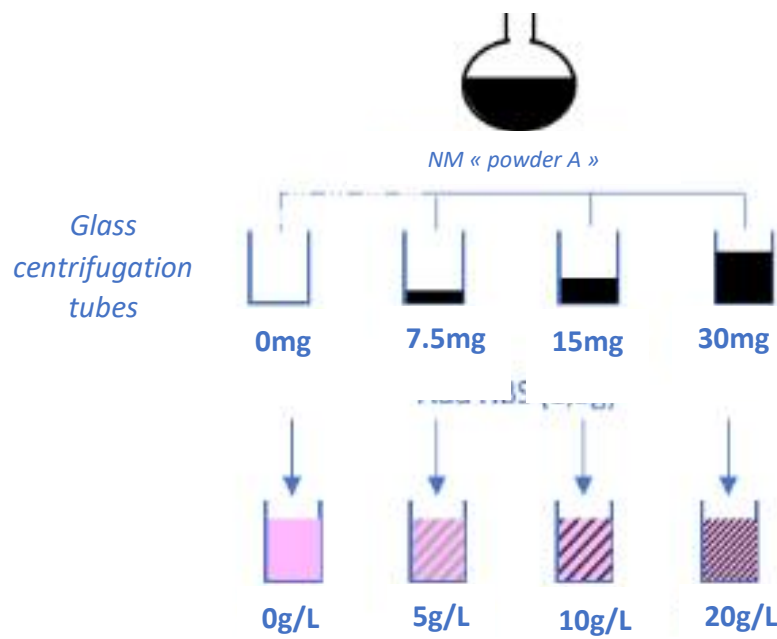

Sonication $10 \mathrm{~min}\left(130 \mathrm{~Hz}, 20^{\circ} \mathrm{C}\right)$

2. Incubation $3 \mathrm{~h}\left(400 \mathrm{rpm}, 37^{\circ} \mathrm{C}\right)$

3. Centrifugation $2 \mathrm{~h} 30 \mathrm{~min}\left(4690 \mathrm{rpm}, 20^{\circ} \mathrm{C}\right)$

4. Collect supernatant

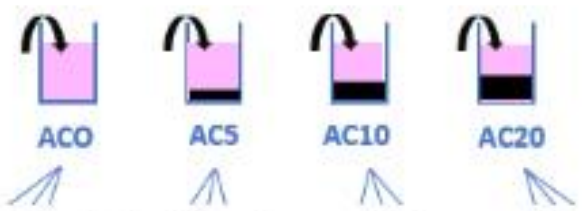

For calibration step (done at least twice for each bottle of human blood serum you will need)

1. Prepare Trolox dilutions in water

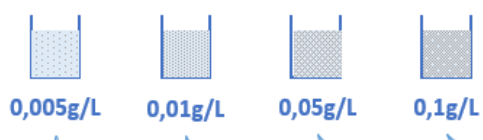

$0,001 \mathrm{~g} / \mathrm{L} \quad 0,005 \mathrm{~g} / \mathrm{L} \quad 0,01 \mathrm{~g} / \mathrm{L} \quad 0,05 \mathrm{~g} / \mathrm{L} \quad 0,1 \mathrm{~g} / \mathrm{L}$

2. Transfer $100 \mu \mathrm{L}$ of each solution in a glass container containing $2 \mathrm{~g}$ of FRAS reagant

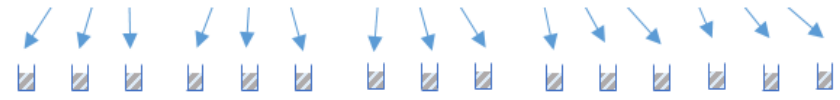

3. Incubation of $60 \mathrm{~min}$

4. Read the absorbance at $500-700 \mathrm{~nm}$

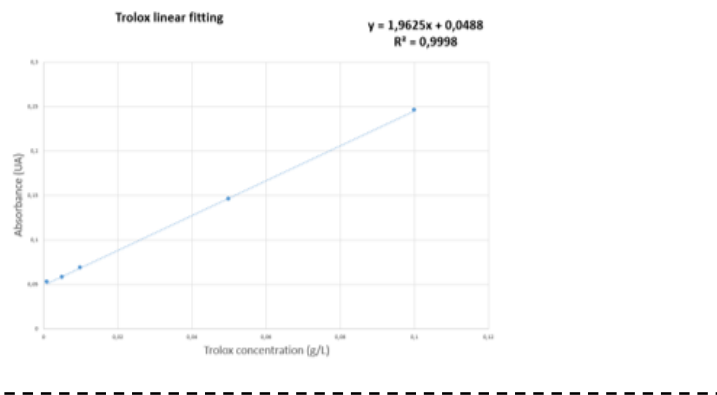

5. Transfer $100 \mu \mathrm{L}$ of supernatant in a glass container containing $2 \mathrm{~L}$ of FRAS reagent

\section{ACO ACO ACO ${ }^{\circ}$ ACS ACS ACS" AC10 AC10 AC10" ACDO ACDO ACZO"

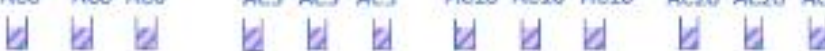 \\ 6. Incubation of $60 \mathrm{~min}$}

Read the absorbance at $500-700 \mathrm{~nm}$ (expected peak at $593 \mathrm{~nm}$ )

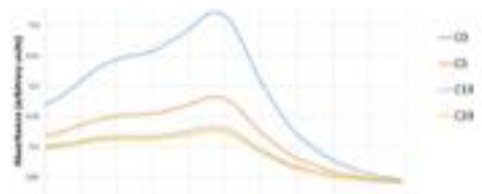

FRAS Protocol. NM: nanomaterials and HBS: human blood serum 
Supplementary data 3: List of equipment and chemicals used

\begin{tabular}{|c|c|}
\hline EQUIPMENTS USED & CHEMICALS USED \\
\hline $\begin{array}{c}\text { ADVENTURER }^{\circledast} \text { PRO ANALYTICAL Balance } \\
\text { (OHAUS) }\end{array}$ & Human serum, HIV tested (VWR) \\
\hline $\begin{array}{l}\text { Centrifuge glass tube, diameter } 12 \mathrm{~mm} \text { and } \\
\text { heigh } 75 \mathrm{~mm} \text { with plastic cap (MC2) }\end{array}$ & $\begin{array}{l}\text { Deionised water, preped with Compact Series } \\
\text { (SG water) }\end{array}$ \\
\hline Heating bath AQUALINE AL (LAUDA) & $\begin{array}{c}\text { 2,4,6-Tri(2-pyridyl)-1,3,5-triazine, 98\% (Alfa } \\
\text { Aesar) }\end{array}$ \\
\hline $\begin{array}{c}\text { Pasteur Pipette, lenght } 270 \mathrm{~mm} \text {, glass (Fisher } \\
\text { brand) }\end{array}$ & $\begin{array}{c}\text { Iron(III) chloride hexahydrate } 99.0-102.0 \% \text {, } \\
\text { AnalaR Reag. Ph. Eur. analytical reagent } \\
\text { (NORMAPUR }{ }^{\circledR} \text { ACS) }\end{array}$ \\
\hline $\begin{array}{c}\text { ADVENTURER }^{\circledast} \text { PRO ANALYTICAL Balance } \\
\text { (OHAUS) }\end{array}$ & $\begin{array}{c}36289 \text { Acetic acid, glacial, ACS, 99.7+\% (Afla } \\
\text { Aesar) }\end{array}$ \\
\hline Ultrasonics Bath ( Branson) & $\begin{array}{c}\text { Sodium acetate trihydrate } 99.0-101.0 \%, \\
\text { AnalaR }^{\circledR}, \text { Reag. Ph. Eur. analytical reagent } \\
\text { (NORMAPUR }{ }^{\circledR} \text { ACS) }\end{array}$ \\
\hline Tritramax Agitator (Heidolph) & $\begin{array}{c}\text { Hydrochloric Acid Solution } 1 \mathrm{M}(1 \mathrm{~N}) \text {, NIST } \\
\text { Standard Solution, ready to use, for volumetric } \\
\text { analysis, (Fisher Chemical }{ }^{\mathrm{TM}} \text { ) }\end{array}$ \\
\hline ThermoMixer $\mathrm{C}$ with Thermotop (Fisher) & Manganese(III) oxide $\geq 98 \%$ (Alfa Aesar) \\
\hline Heraeus Megafuge Centrifuge (Thermo) & $\begin{array}{l}\text { 6-Hydroxy-2,5,7,8-tetramethylchroman-2- } \\
\text { carboxylic cid 97\% (Acros Organics) }\end{array}$ \\
\hline $\begin{array}{l}\text { Spectrophotometer MULTISKAN GO + (Thermo } \\
\text { scientific) }\end{array}$ & \\
\hline $\begin{array}{l}\text { Quartz cell SUPRASIL, light path } 3 \times 3 \mathrm{~mm} \text { (Hellma } \\
\text { Analytics) }\end{array}$ & \\
\hline $\begin{array}{c}\text { Graduated pipettes, }(2 \mathrm{~mL} \text {, Division } 0,02 \mathrm{ml}) \text { in } \\
\text { glass, }\left(\mathrm{VWR}^{\circledR}\right)\end{array}$ & \\
\hline $\begin{array}{c}\text { Graduated pipettes, }(1 \mathrm{~mL} \text {, Division 0,01 ml) in } \\
\text { glass, }\left(\mathrm{VWR}^{\oplus}\right)\end{array}$ & \\
\hline Wizard $^{\mathrm{TM}}$ Infrared Vortex Mixer (Fisherbrand ${ }^{\mathrm{TM}}$ ) & \\
\hline $\begin{array}{l}\text { Borosilicate Glass Scintillation Vials, with White } \\
\text { Polypropylene Caps (Fisherbrand }{ }^{\mathrm{TM}} \text { ) }\end{array}$ & \\
\hline $\begin{array}{c}25 \mathrm{~mm} \text { serynge filter PTFE hydrophylic, 0,2 } \mu \mathrm{m} \\
\text { (Fisherbrand }{ }^{\mathrm{TM}} \text { ) }\end{array}$ & \\
\hline $\begin{array}{c}\text { TERUMO SYRINGE WITHOUT NEEDLE 5mL } \\
\text { (TERUMO) }\end{array}$ & \\
\hline
\end{tabular}


Supplementary data 4: Labelling the supernatant and reaction vials

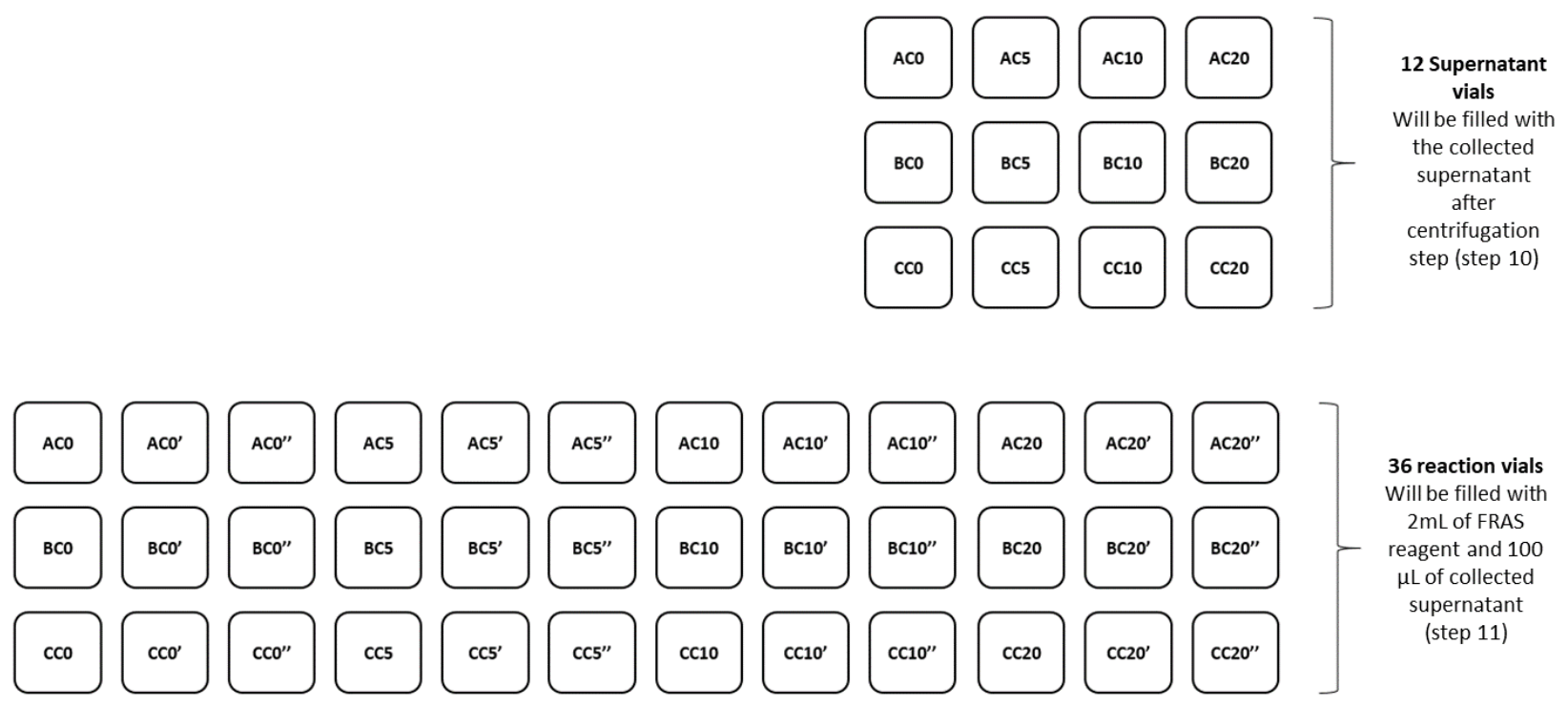


Supplementary data 5: Pictures of low-density graphene-based materials solutions and filtration.
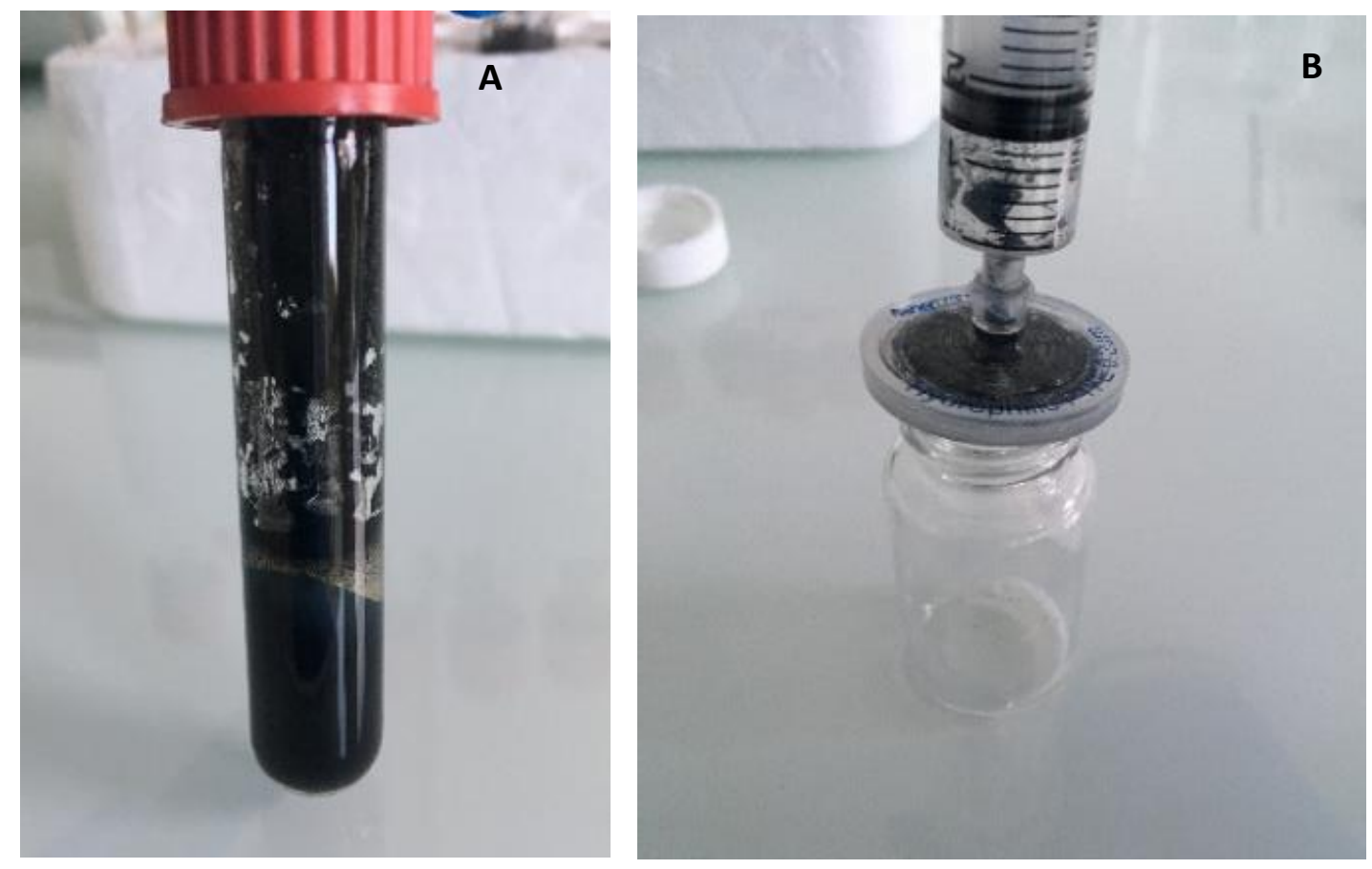

Low density GBMs in HBS after centrifugation, $10 \mathrm{~g} / L$ concentration (A) and filtration (B). Please note that the filtrate should be clear. 


\section{Supplementary data 6: Explanation and example of calculations for one sample.}

When we obtained the results in absorbance units, the first step was to calculate the Biological Oxidative Damage (BOD) and convert these results in Trolox Equivalent Unit (TEU). Each BOD is calculated at an exposure concentration, as presented in Equation 1. In our case, the exposure concentrations $C_{x}$ were 5,10 and $20 \mathrm{~g} / \mathrm{L}$. We hence calculated $\mathrm{BOD}_{\mathrm{C} 5}, \mathrm{BOD}_{\mathrm{C} 10}$ and $\mathrm{BOD}_{\mathrm{C} 20}$.

$$
\text { Equation 1: } \quad \mathrm{BOD}_{\mathrm{Cx}_{\mathrm{x}}}=\frac{(\text { Abs at } 593 \mathrm{nmC} \mathrm{C}-)-(\text { Abs at } 593 \mathrm{nmCx})}{K e * l * d}[\text { in } \mathrm{mM} \text { TEU] }
$$

Where:

- Abs at $593 \mathrm{~nm} \mathrm{C-}=$ Measured absorbance at $593 \mathrm{~nm}$ of the C- (blank, only HBS) solution.

- Abs at $593 \mathrm{~nm} \mathrm{C} C_{x}=$ Measured absorbance at $593 \mathrm{~nm}$ of the $C_{x}$ solution.

- $\mathrm{Ke}{ }^{*}{ }^{*} \mathrm{~d}=$ Obtained with Trolox calibration (see section 5.a).

This BOD measurement is useful for having access to the raw effect of each nanomaterials. However, for a measurement of surface reactivity, it is often necessary to introduce the specific surface area of each nanomaterial in the results, as for the surface-based BOD. We might also need to standardize the BOD with the concentration of nanomaterials used, with masse-based BOD. Then, we calculated the mass-based BOD ( $m B O D$, see equation 2) and the surface-based BOD ( $\triangle B O D$, see equation 4 ) with the help of the Dose of nanomaterial at each concentration (Dose $e_{x}$, see equation 3 )

$$
\text { Equation 2: } \quad \mathrm{mBOD}=\frac{\mathrm{BOD} \mathrm{cx}}{\mathrm{cx}}[\text { in } \mathrm{nM} \mathrm{TEU} / \mathrm{mg}]
$$

Where:

- $\mathrm{BOD}_{\mathrm{cx}}$ was calculated with equation 1 (in $\mathrm{mMTEU}$ )

- $\mathrm{Cx}$ is the exposure concentration (in $\mathrm{g} / \mathrm{L}$ )

Equation 3: $\quad$ Dose $_{\mathrm{x}}=\mathrm{C}_{\mathrm{x}} *$ SSA [in $\left.\mathrm{m}^{2} / \mathrm{L}\right]$

Where:

- $\quad \mathrm{Cx}$ is the exposure concentration (in $\mathrm{g} / \mathrm{L}$ )

- SSA is the specific surface area, obtained with BET measurement (in $\mathrm{m}^{2} / \mathrm{g}$ )

$$
\text { Equation 4: } \quad \mathrm{sBOD}=\frac{\mathrm{BOD} \mathrm{Cx}}{\text { Dosex }}\left[\text { in } \mathrm{nM} \mathrm{TEU} / \mathrm{m}^{2}\right]
$$

Where:

- $\mathrm{BOD}_{\mathrm{Cx}}$ is obtained in equation 1

- Dose $_{x}$ is obtained in equation 3

For a better understanding of the calculations, we present a step-by-step explanation of an analysis of a specific GBM, as an example, in supplementary data 4. 


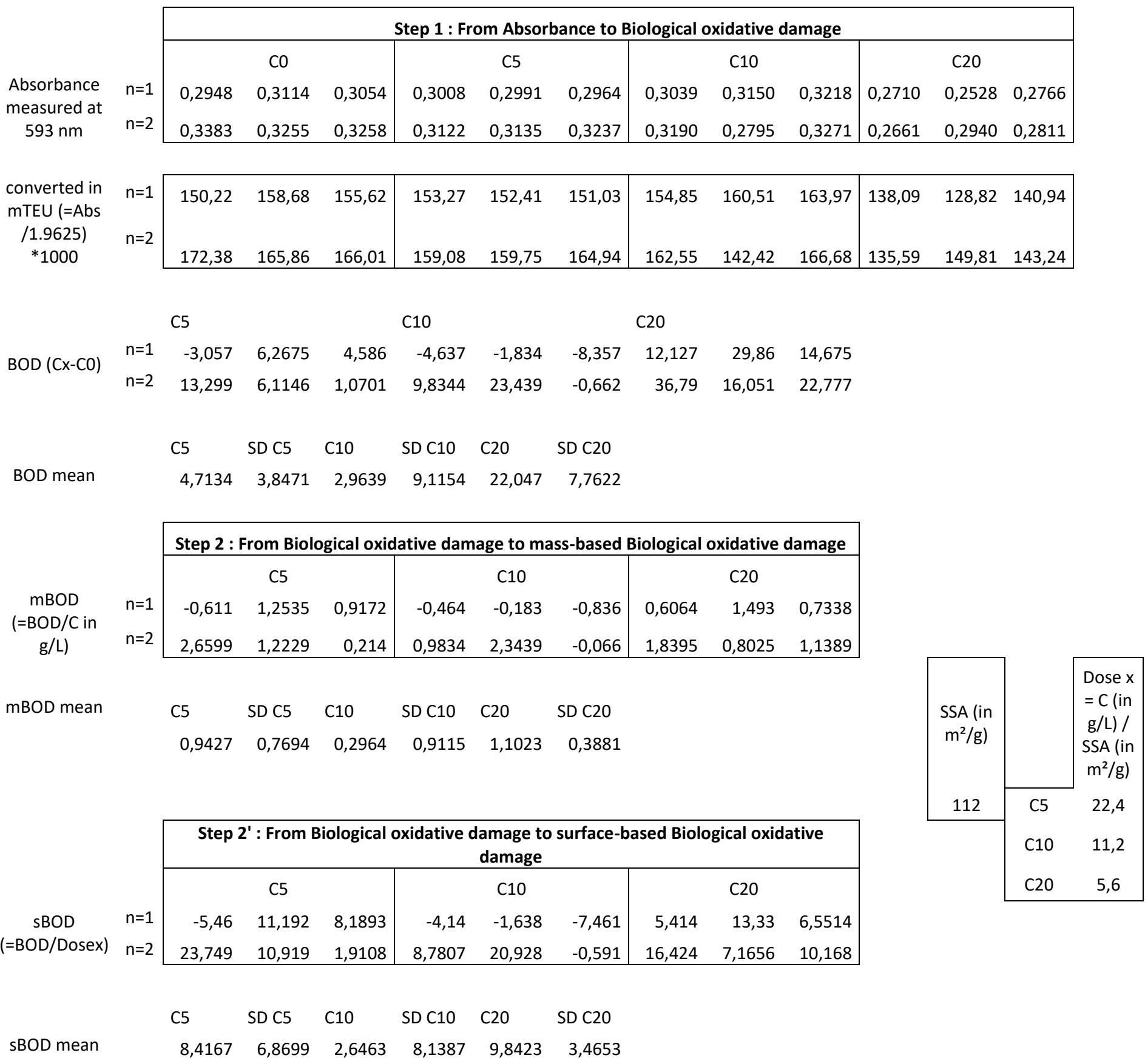




\section{Supplementary data 7: Table presenting the previous results of the FRAS assay for graphene or carbon black materials.}

\begin{tabular}{|c|c|c|c|c|c|c|c|c|}
\hline & Title & Year & Authors & $\begin{array}{c}\text { Studied } \\
\text { nanomaterial }\end{array}$ & $\begin{array}{l}\text { Physicochemical } \\
\text { characteristics }\end{array}$ & BOD & sBOD & mBOD \\
\hline \multirow{3}{*}{1} & \multirow{3}{*}{$\begin{array}{l}\text { Case studies putting } \\
\text { the decision-making } \\
\text { framework for the } \\
\text { grouping and } \\
\text { testing of } \\
\text { nanomaterials } \\
\text { (DF4nanoGrouping) } \\
\text { into practice }\end{array}$} & \multirow{3}{*}{2015} & \multirow{3}{*}{$\begin{array}{c}\text { Josje H E Arts, } \\
\text { Muhammad-Adeel } \\
\text { Irfan , Athena M } \\
\text { Keene, Reinhard } \\
\text { Kreiling, Delina } \\
\text { Lyon, Monika Maier } \\
\text {, Karin Michel, } \\
\text { Nicole Neubauer, } \\
\text { Thomas Petry, } \\
\text { Ursula G Sauer, } \\
\text { David Warheit, } \\
\text { Karin Wiench, } \\
\text { Wendel Wohlleben } \\
\text {, Robert Landsiedel } \\
\end{array}$} & $\begin{array}{l}\text { Graphene / } \\
\text { Graphite } \\
\text { nanoplatelets }\end{array}$ & N/A & \multicolumn{3}{|c|}{$\begin{array}{l}\text { With the present protocol, determination not } \\
\text { possible due to high substance hydrophobicity }\end{array}$} \\
\hline & & & & $\begin{array}{l}\text { Low surface } \\
\text { carbon Black }\end{array}$ & N/A & \multicolumn{3}{|c|}{$\begin{array}{l}\text { Low surface reactivity * results from Hsieh et al. } \\
\qquad(2013)\end{array}$} \\
\hline & & & & $\begin{array}{l}\text { Various } \\
\text { Amorphous } \\
\text { Silica }\end{array}$ & $\begin{array}{l}12-20 \mathrm{~nm} \\
\text { (spherical) }\end{array}$ & & $\begin{array}{c}\text { From } 5.9 \text { to } 15 \\
\text { nUFRAS/m² } \\
\text { classified as non- } \\
\text { oxidative }{ }^{*} \text { from } \\
\text { an unpublished } \\
\text { report. }\end{array}$ & \\
\hline \multirow{3}{*}{2} & \multirow{3}{*}{$\begin{array}{l}\text { Mapping the } \\
\text { Biological Oxidative } \\
\text { Damage of } \\
\text { Engineered } \\
\text { Nanomaterials }\end{array}$} & \multirow{3}{*}{2013} & \multirow{3}{*}{$\begin{array}{l}\text { Shu-Feng Hsieh, } \\
\text { Dhimiter Bello, } \\
\text { Daniel F. Schmidt, } \\
\text { Anoop K. Pal , } \\
\text { Aaron Stella } \\
\text {,Jacqueline A. Isaacs } \\
\text {, and Eugene J. } \\
\text { Rogers }\end{array}$} & Graphene & $\begin{array}{c}\text { primary particle } \\
\text { size }=500 \mathrm{~nm} \\
\mathrm{SSA}=94-100 \mathrm{~m}^{2} / \mathrm{g}\end{array}$ & & $\begin{array}{c}\text { 92-103 sBOD } \\
\text { [nmol TEUs } / \mathrm{m}^{2} \text { ] } \\
\text { Q3 classification } \\
\text { for rank sBOD }\end{array}$ & $\begin{array}{c}9-10 \\
\mathrm{mBOD}[\mathrm{nmol} \\
\text { TEUs/mg] }\end{array}$ \\
\hline & & & & Carbon Black & $\begin{array}{l}\text { primary particle } \\
\text { size }=14-395 \mathrm{~nm} \\
\mathrm{SSA}=8-300 \mathrm{~m}^{2} / \mathrm{g}\end{array}$ & & $\begin{array}{c}\text { 38-85 sBOD } \\
\text { [nmol TEUs } / \mathrm{m}^{2} \text { ] } \\
\text { Q2 classification } \\
\text { for rank sBOD }\end{array}$ & $\begin{array}{l}\text { 2-21 mBOD } \\
\text { [nmol } \\
\text { TEUs/mg] }\end{array}$ \\
\hline & & & & $\begin{array}{l}\text { Amorphous } \\
\text { silica }\end{array}$ & N/A & & $\mathrm{N} / \mathrm{A}$ & \\
\hline \multirow{3}{*}{3} & \multirow{3}{*}{$\begin{array}{l}\text { Screening for } \\
\text { oxidative damage } \\
\text { by engineered } \\
\text { nanomaterials: A } \\
\text { comparative } \\
\text { evaluation of FRAS } \\
\text { and DCFH }\end{array}$} & \multirow{3}{*}{2014} & \multirow{3}{*}{$\begin{array}{c}\text { Anoop K. Pal, Shu- } \\
\text { Feng Hsieh, Madhu } \\
\text { Khatri, Jacqueline A. } \\
\text { Isaacs, Philip } \\
\text { Demokritou, Peter } \\
\text { Gaines, Daniel F. } \\
\text { Schmidt, Eugene J. } \\
\text { Rogers \& Dhimiter } \\
\text { Bello }\end{array}$} & Graphene & N/A & & N/A & \\
\hline & & & & Carbon Black & $\begin{array}{l}\text { CB N110 with BET } \\
=110,6 \mathrm{~m}^{2} / \mathrm{g} \text { and } \\
\text { primary particle } \\
\text { size }=15 \mathrm{~nm} \\
\text { CBN550 with BET } \\
=39,2 \mathrm{~m}^{2} / \mathrm{g} \text { and } \\
\text { primary particle } \\
\text { size }=44 \mathrm{~nm}\end{array}$ & & $\begin{array}{l}\text { CB N110: sBOD } \\
=85\left[\mathrm{nmol} / \mathrm{m}^{2}\right] \\
\text { CB N550:sBOD } \\
=157\left[\mathrm{nmol} / \mathrm{m}^{2}\right]\end{array}$ & $\begin{array}{l}\mathrm{CB} \mathrm{N} 110: \\
\mathrm{mBOD}=9 \\
{[\mathrm{nmol} / \mathrm{mg}]} \\
\mathrm{CB} \mathrm{N550:} \\
\mathrm{mBOD}=6 \\
{[\mathrm{nmol} / \mathrm{mg}]}\end{array}$ \\
\hline & & & & $\begin{array}{l}\text { Amorphous } \\
\text { silica }\end{array}$ & $\mathrm{N} / \mathrm{A}$ & & N/A & \\
\hline \multirow{3}{*}{4} & \multirow{3}{*}{$\begin{array}{l}\text { Biological oxidative } \\
\text { damage by carbon } \\
\text { nanotubes: } \\
\text { Fingerprint or } \\
\text { footprint? }\end{array}$} & \multirow{3}{*}{2012} & \multirow{3}{*}{$\begin{array}{l}\text { Shu-Feng Hsieh 1, } \\
\text { Dhimiter Bello, } \\
\text { Daniel F Schmidt, } \\
\text { Anoop K Pal, } \\
\text { Eugene J Rogers }\end{array}$} & Graphene & N/A & & N/A & \\
\hline & & & & Carbon Black & $\begin{array}{l}\mathrm{N} 110: 20-25 \mathrm{~nm}, \\
\mathrm{BET}=110,6 \mathrm{~m}^{2} / \mathrm{g}\end{array}$ & $\begin{array}{c}\mathrm{BOD}(\mathrm{mMTEU})= \\
0.937\end{array}$ & $\begin{aligned} \mathrm{sBOD} & \left(\mathrm{nmol} / \mathrm{m}^{2}\right) \\
& =80\end{aligned}$ & $\begin{array}{c}\mathrm{mBOD}(\mathrm{nmol} \\
/ \mathrm{mg})=9\end{array}$ \\
\hline & & & & $\begin{array}{l}\text { Amorphous } \\
\text { silica }\end{array}$ & N/A & & N/A & \\
\hline \multirow{3}{*}{5} & \multirow{3}{*}{$\begin{array}{l}\text { Nanomaterials } \\
\text { properties vs. } \\
\text { biological oxidative } \\
\text { damage: } \\
\text { Implications for } \\
\text { toxicity screening } \\
\text { and exposure } \\
\text { assessment }\end{array}$} & \multirow{3}{*}{2009} & \multirow{3}{*}{$\begin{array}{l}\text { Dhimiter Bello Shu- } \\
\text { Feng Hsieh Daniel } \\
\text { Frederick Schmidt } \\
\text { Eugene Rogers }\end{array}$} & Graphene & N/A & & N/A & \\
\hline & & & & Carbon Black & $\begin{array}{l}\mathrm{N} 110: 15 \mathrm{~nm}, \mathrm{BET} \\
=110,6 \mathrm{~m}^{2} / \mathrm{g} \\
\text { N550: } 44 \mathrm{~nm}, \mathrm{BET} \\
=39,2 \mathrm{~m}^{2} / \mathrm{g} \\
\mathrm{N} 990:>200 \mathrm{~nm}, \\
\text { BET }=7,7 \mathrm{~m}^{2} / \mathrm{g}\end{array}$ & $\begin{array}{c}\text { N110: Mean } \\
\text { BOD [mMTEU]= } \\
0.937 \\
\text { N550: Mean } \\
\text { BOD [mMTEU]= } \\
0.614 \\
\text { N990: Mean } \\
\text { BOD [mMTEU = } \\
0.413\end{array}$ & & \\
\hline & & & & $\begin{array}{l}\text { Amorphous } \\
\text { silica }\end{array}$ & N/A & & N/A & \\
\hline
\end{tabular}


Supplementary data 8: Replicability of the assay, intra and inter experiment: antioxidant capacity of the serum

Assessing our samples required a total of $360 \mathrm{~mL}$ of HBS which represents several bottles. Even if we ordered the same reference with the same supplier, we wanted to be sure that we did not have a significant variability of its total antioxidant capacity depending on the batch, for example. For each nanomaterial testing, we measured the absorbance of the HBS alone. We found that its antioxidant capacity was stable, with a value of $168.6 \pm 6.64 \mu \mathrm{MTEU}$.

However, we observed a slight variation with the values obtained in previous papers (Gandon et al., Hiesh et al.,) where these values were respectively $366 \mu \mathrm{MTEU}$ and $530 \mu \mathrm{MTEU}$ (for the last value, it was indicated 530 mMTEU but we assume it was a typo).

While remaining very stable through our experiments, it appears that the grade and source of the serum has a notable influence on its total antioxidant capacity. The biological oxidative damage is based on the relative change between the non-exposed HBS and the exposed HBS, lowering the impact of this variability. However, we recommend working on the same reference of HBS when possible and to assess the antioxidant capacity of the HBS regularly during the testing. 